\title{
Volcanic ashfall preparedness poster series: a collaborative process for reducing the vulnerability of critical infrastructure
}

\author{
Thomas M Wilson 1*, Carol Stewart 1,2, Johnny B Wardman', Grant Wilson ${ }^{1}$, David M Johnston 1,2, Daniel Hill', \\ Samuel J Hampton ${ }^{1}$, Marlene Villemure ${ }^{1}$, Sara McBride ${ }^{2}$, Graham Leonard ${ }^{2,3}$, Michele Daly ${ }^{3}$, Natalia Deligne ${ }^{3}$ \\ and Lisa Roberts ${ }^{4}$
}

\begin{abstract}
Volcanic ashfall can be damaging and disruptive to critical infrastructure including electricity generation, transmission and distribution networks, drinking-water and wastewater treatment plants, roads, airports and communications networks. There is growing evidence that a range of preparedness and mitigation strategies can reduce ashfall impacts for critical infrastructure organisations. This paper describes a collaborative process used to create a suite of ten posters designed to improve the resilience of critical infrastructure organisations to volcanic ashfall hazards. Key features of this process were: 1) a partnership between critical infrastructure managers and other relevant government agencies with volcanic impact scientists, including extensive consultation and review phases; and 2) translation of volcanic impact research into practical management tools. Whilst these posters have been developed specifically for use in New Zealand, we propose that this development process has more widely applicable value for strengthening volcanic risk resilience in other settings.
\end{abstract}

Keywords: Hazard; Risk; Tephra; Preparedness; Critical infrastructure; Airport; Electricity; Transmission; Distribution; Generation; Water supply; Wastewater; Buildings; Road; Transport; HVAC; Computer; Electronics; Risk communication

\section{Introduction}

Volcanic ashfall can cause a range of societal impacts. Ashfalls of just a few $\mathrm{mm}$ can be damaging and disruptive to critical infrastructure services (also known as 'utilities' in some countries), such as electricity generation, transmission and distribution networks, drinking-water and wastewater treatment plants, roads, airports and communication networks (Wilson et al. 2012b). Disruption of service delivery can have cascading impacts on wider society. Ashfall can be very widely distributed, potentially affecting communities hundreds of kilometres from the erupting volcano. For example, the recent June 2011 eruption of Puyehue-Cordón Caulle volcanic complex, in southern Chile, deposited ashfall over approximately 75,000 km² of Argentinian Patagonia (Buteler et al. 2011), with a substantial depth of $30-45 \mathrm{~mm}$ deposited on

\footnotetext{
* Correspondence: thomas.wilson@canterbury.ac.nz

${ }^{1}$ Volcanic Ash Testing Lab, Department of Geological Sciences, University of Canterbury, Private Bag 4800, Christchurch 8140, New Zealand

Full list of author information is available at the end of the article
}

the major regional centre of San Carlos de Bariloche, population approximately 113,000 . This led to extensive disruption of the city's water supply, electricity distribution and generation networks, wastewater networks, ground and air transportation networks, and necessitated a major ash clean-up operation within the town (Wilson et al. 2012c). Specific impacts of ashfall vary considerably, depending on factors such as plant or network design, ashfall characteristics (e.g. loading, grain-size, composition and levels of leachable elements), and environmental conditions before and after the ashfall.

There is also growing evidence that a range of preparedness and mitigation strategies can reduce ashfall impacts (Wardman et al. 2012a, Sword-Daniels et al. 2014). Core components of disaster risk reduction includes (1) providing advice on likely impacts and best-practice mitigation strategies, and (2) encouraging communities or organisations to adopt preparedness measures which increase their ability to manage hazard consequences, and thus increasing their capacity to manage risk (Paton et al. 2008; 
UNISDR 2011). However, this is not as simple as it seems. Firstly, empowering society to utilise scientific and technological advances to reduce the impacts of disasters is a well-established challenge (Tobin and Montz 1997; Miletti 1999; Alexander 2007; ICSU 2003, 2010; UNISDR 2011; Few and Barclay 2011; McBean 2012). Both the UNISDR Hyogo Framework for Action (HFA) and Integrated Research on Disaster Risk (IRDR) program to call for more integration of research with the needs of policy and decision makers (ICSU 2008). Few and Barclay (2011) also stress the need to promote integrated, inter-disciplinary approaches, strengthen two-way links between research providers and end-users, and increase experimentation with research mechanisms (such as 'embedded' approaches) to support more effective research/end-user partnerships.

Secondly, a review of recent risk perception and preparedness studies by Wachinger et al. (2013) suggests that even if an individual perceives a high level of risk from a given hazard, this does not necessarily translate into this individual adopting appropriate risk mitigation behaviour for that given hazard. Ballantyne et al. (2000) found that provision of hazard information by agencies can, paradoxically, decrease a community's perceived need to prepare as they will tend to transfer responsibility to these agencies. In the case of volcanic hazards, knowledge of proximity to volcanic hazards or susceptibility to their consequences does not assure mitigative actions will be taken, and preparedness levels often remain low in proximal regions even in developed countries (Paton et al. 2008). Even experiencing a volcanic eruption may not necessarily act as a catalyst for preparing for a future event (Johnston et al. 1999). These effects may be even more pronounced as eruptions are relatively infrequent and 'exotic' (Paton et al. 1998). For risk communication, simply providing information often fails to change risk perception or motivate volcanic hazard preparedness, implying that more engaged and appropriate strategies are required (Paton et al. 2008). This may be overcome by a more participatory process (Twigg 2007). When stakeholders (e.g. communities and organisations) actively participate as legitimate partners in the communication (and mitigation) exercise, they are empowered to make change which increases their resilience (Covello and Allen 1988; Paton et al. 2005). The communication exercise should also be transparent and led by a source which is authoritative, credible and trusted (Berlo 1960).

This paper describes an example of this approach, a collaborative process used to develop a suite of posters which summarise the potential impacts of volcanic ash and preparedness and mitigation strategies for different sectors of critical infrastructure. The effort included sustained exchange and development of best practices through collaboration among researchers, infrastructure managers and emergency managers from within an established practitioner-research volcanic impact advice structure in New Zealand.

\section{Evolution of volcanic emergency management structures in New Zealand \\ Context: 1995-96 Ruapehu eruption sequence}

Over the past two decades there has been growing awareness in New Zealand (as for many other nations) that volcanic hazards can cause substantial and unique impacts on critical infrastructure (known as 'lifelines' in New Zealand). Consequently, a strong culture of natural hazard risk management within the critical infrastructure sector in New Zealand has developed, catalysed through the development of 'regional engineering lifeline groups' which are defined as "an informal, regionally-based process of lifeline utility representatives working with scientists, engineers and emergency managers to identify interdependencies and vulnerabilities to regional scale emergencies. This collaborative process provides a framework to enable integration of asset management, risk management and emergency management across utilities." (NELC, 2007). Typically seismic, storm and flood hazards have been the focus, with well-established, evidence-based design codes and advice for preparedness and response strategies available (e.g. the Civil Defence and Emergency Management Act 2002, the Building Act 2004 and the Resource Management Act 1991 of the New Zealand Parliament). By comparison, volcanic hazards have received less attention. This disparity can be at least partially attributed to few, damaging volcanic events occurring during the past 60 years in New Zealand (OCDESC, 2007). However the 1995-96 eruption of Ruapehu volcano caused widespread and costly impacts to a range of critical infrastructure organisations in New Zealand, despite the relatively modest eruption magnitude (Johnston et al. 2000). The risk of lahars, blasts and surges closed all three ski fields on Ruapehu for many months while volcanic ashfall and lahars impacted critical infrastructure, agriculture and communities many tens to hundreds of kilometres from the volcano. Total losses were an estimated NZ\$130 million ( NZ\$188 million or US\$161 million in 2014) (Johnston et al. 2000). Analysis of the performance of responding organisations (national, regional and local government agencies, utilities, emergency services and private businesses) by Paton et al. (1998) found there was insufficient knowledge of volcanic hazard impact and appropriate mitigation strategies within these organisations. Nor was there sufficient access to information, which further exacerbated uncertainty regarding preparedness, response and mitigation decision-making. Many organisations looked to the government volcano 
monitoring agency (formerly the Institute of Geological and Nuclear Sciences, now GNS Science) and the universities for specialist impact and mitigation advice. However, there was limited volcanic impact information easily available, either within New Zealand or internationally (Johnston et al. 2000).

The Ruapehu crisis was exacerbated by relatively rigid, top-down, siloed management structures at local and regional levels which did not cope well with the impacts occurring across a complex multijurisdictional setting (Paton et al. 1998). In particular, pre-existing networks between information providers and responders were found to be incomplete and inconsistent with respect to information needs. This detracted from effective communication between organisations hampered decision-making and coordination in an environment characterised by multi-organisational involvement and conflicting demands (Paton et al. 1998).

Most organizations emerged from the Ruapehu disaster relatively unaffected, and many perceived that they had coped effectively with the demands of the disaster. However Paton et al. (1998) argued that this may "stimulate overestimation of future response capability, underestimation of risk, and constrain thinking about future events, making it difficult to conceptualise alternative demands, problems or outcomes... and may ignore the negative outcomes or potential inadequacies of crisis management systems." These authors argued that it was important to ensure that this experience did not result in complacency about future response effectiveness.

\section{Implementing lessons learned}

In the five to ten years after the Ruapehu eruptions, New Zealand's approach to emergency management has evolved from a 'civil defence' approach to a 'comprehensive emergency management' approach with the passage of the Civil Defence and Emergency Management (CDEM) Act in 2002. This act recognised the unique challenges of managing disasters and emergencies, and stipulated a more coordinated, integrated approach which focused on developing partnerships and clarifying emergency management responsibilities of critical infrastructure companies.

In this changing environment, the lessons from the 1995-96 Ruapehu eruption acted as a catalyst for 1) developing a volcanic impact evidence base to inform preparedness and mitigation decision-making (particularly for ashfall as the most frequently-produced and widelydistributed volcanic hazard); and 2) enhancing communication and coordination structures between volcano and risk scientists and stakeholders (Paton et al. 1998; Johnston et al. 2000; Leonard et al. 2008).

\section{Volcanic impacts research group}

As part of New Zealand's increased investment in applied volcanology research over the past 15 years, a volcanic impact research group was formed between GNS Science and partner universities (University of Canterbury, Massey University, and University of Auckland). This group has pursued a sustained and systematic approach to assessing the impact of volcanic ash on critical infrastructure, for as wide a range of different eruption types and magnitudes. This group has undertaken reconnaissance trips to areas impacted by volcanic eruptions worldwide at varying intervals after the eruption, to capture both short and longer term impacts, timescales of recovery, successful mitigation strategies and overall management lessons (Table 1). A further goal is to develop quantitative risk tools, such as vulnerability and fragility functions that relate impacts to the amount and characteristics of ashfall received and to develop more quantitative relationships for use in risk modelling. The group has also studied cascading impacts of ashfall within a systems-thinking framework (Wilson et al. 2012b; Sword-Daniels et al. 2014). More recently, empirical laboratory-based testing of critical infrastructure components has been conducted in our Volcanic Ash Testing Lab (VAT Lab) (Wilson et al. 2012a; Wardman et al. 2012b). The strategic focus of the full research group has been on understanding both ashfall impacts on individual system components and overall system functionality. The group has received ongoing funding support from the Natural Hazard Resource Platform (a multi-party research platform funded by the New Zealand Government dedicated to increasing New Zealand's resilience to Natural Hazards via high quality collaborative research), critical infrastructure organisations (primarily AELG organisations, described in the following section), and the New Zealand Earthquake Commission. In kind funding support from.

\section{Provision and coordination of volcanic impact knowledge}

In conjunction with development of the research group, an enhanced partnership with end-users needed to be established for communicating volcanic impact science both during crisis and non-crisis periods. The Auckland Engineering Lifelines Group (AELG) is a group of critical infrastructure organisations within the Auckland region. Its mission is to increase critical infrastructure resilience to all hazards. As such, there was considerable interest within AELG to enhance volcanic impact science capability. Volcanic hazards are one of the most substantial risks to the Auckland region, either from an eruption from the Auckland Volcanic Field upon which the city is built or from distal ashfall hazards from central North Island volcanoes. In 2004, the Volcanic Impact Study Group (VISG) was established as a subcommittee of the AELG. The VISG was designed to be a 
Table 1 List of volcanic impact reconnaissance trips undertaken by New Zealand volcanic impact research group

\begin{tabular}{llll}
\hline Volcano & Country & Year of eruption & Year of assessment trip \\
\hline Mt St Helens & USA & 1980 & 1995 \\
Crater Peak (Mt Spurr) & USA & 1989 & 1996 \\
Sakura-jima & Japan & $\sim 1980-2000$ & 2001 \\
Ruapehu & New Zealand & $1995-96$ & $1995-97$ \\
Etna & Italy & 2003 & 2003 (several days after) \\
Tungurahua \& Reventador & Ecuador & $1999-2005$ \& 2002 & 2005 \\
Merapi & Indonesia & 2006 & 2006 (1 month after) \\
Pinatubo & Philippines & 1991 & 2007 \\
Eldfell & Iceland & 1973 & 2008 \\
Hudson & Chile & 1991 & 2008 \\
Chaiten & Chile & 2008 & 2009 \\
Redoubt & USA & 2009 & 2009 \\
Pacaya & Guatemala & 2010 & 2010 (4 months after) \\
Tungurahua & Ecuador & 2010 & 2010 (4 months after) \\
Shinmoedake & Japan & 2011 & 2011 (9 months after) \\
Puyehue-Cordón Caulle & Chile & 2011 & 2012 (9 months after) \\
Tongariro & New Zealand & 2012 & 2012 (2-3 days after) \\
\hline & & &
\end{tabular}

multidisciplinary and multi-institution consortium of volcanology and natural hazard researchers and practitioners with the following aims (VISG 2012):

- To collate and advocate existing knowledge about the impacts of volcanic hazards (e.g. ash) on, and mitigation measures for, lifeline infrastructure.

- To facilitate and support research on the impacts of volcanic hazards on lifelines and people, and the development of appropriate mitigation measures.

- To provide input into the applicability for lifelines of any research being undertaken.

- To facilitate reconnaissance investigations, and/or advocate lifeline representation on reconnaissance investigations, to active volcanic areas where this would add to our knowledge about volcanic impacts on infrastructure.

- To provide a national focal point for volcanic impacts work on lifelines.

Initially, the VISG was only focused on the Auckland region and was concerned primarily with impacts from the Auckland volcanic field, an active basaltic scoria cone field upon which Auckland City (pop. 1.5 million) is constructed (Lindsay et al. 2010). This focus has since broadened to support volcanic impacts research with any local, regional or national stakeholder in New Zealand. VISG provides a formalised networked structure between volcanic impact science providers (GNS and the universities) and critical infrastructure and emergency management organisations. Key activities of the VISG include undertaking focused research on volcanic impacts, contributing to volcano contingency planning and exercising when requested, and running an annual seminar on current research.

Communication of appropriate volcanic impact science with end-users in a timely manner during an eruption crisis can be additionally challenging in the absence of adequate training and communication structures linked to expert knowledge. Pre-existing relationships between endusers and researchers, combined with readily available resources, can greatly reduce information searching and processing time, which aids decision-making timeliness and quality (Paton et al. 1998). The VISG aims to improve non-crisis and crisis communication between providers and recipients by developing relationships and resources which anticipate and provide for likely information needs. It fosters a group of information providers who can access, collate, interpret and disseminate information as needed within a known and regularly used framework. Likewise, the interaction with AELG and other lifeline group members contributes to developing a capacity within their own organisations to interpret, request and use specialist volcanic impact information.

Specific activities have included multi-organisation workshops, targeted 'sector specific' workshops, one-on-one meetings and public lecture tours. Information is also provided to international volcanological initiatives, such as the USGS-GNS Volcanic Ash Impacts Website (http:// volcanoes.usgs.gov/ash/), the International Volcanic Health 
Hazard Network (www.ivhhn.org) and the Cities on Volcanoes Commission of IAVCEI (http://cav.volcano.info/).

\section{Poster design}

Critical infrastructure organisations that have experienced adverse impacts during ashfall events commonly report low levels of prior awareness of ashfall hazards and impacts (Blong 1984; Paton et al. 1998; Ronan et al. 2000; Wilson et al. 2012b). Whilst many organisations recognise the value of planning and preparedness for volcanic hazards, the necessary investment can be difficult to justify in the context of a variety of other hazards and business pressures. Feedback from AELG members suggested that lengthy reports summarising known impacts, mitigation options/recommendations and interdependency issues were useful, but only during infrequent detailed planning exercises. Authoritative but concise reference materials preferred as a means to inform planning and be readily available during a crisis, supplemented by additional information from science providers as needed. After some experimentation and consultation, posters were judged to be the optimal method for condensing key impact and mitigation information into a concise, palatable and visible form. The first series of posters was commissioned and completed during the period 2007-2010 for five infrastructure sectors: airports, road networks, drinking-water supplies, power-systems (networks), and wastewater collection and treatment systems (Figures 1, 2, 3, 4, 5). These sectors were selected by AELG and VISG members as most likely to be impacted. This edition of the posters were advertised widely in outreach activities, used during emergency management exercises and ultimately became a recognised information source in New Zealand (Bay of Plenty Engineering Lifelines Coordinator pers. comm. 2012).

During subsequent review of VISG resources and risk communication strategy, it became apparent that the content of the first series of posters was becoming outdated; for example, global initiatives in the aviation sector (ICAO, 2007) needed to be incorporated into advice. Thus it was decided in 2012 that a) the current poster suite should be updated with the latest research and accounting for local and global developments, and b) that additional posters should be developed to address knowledge gaps. Subjects of particular interest were advice on ash cleanup operations for city authorities; impacts on building facilities; impacts on heating, ventilation and air-conditioning (HVAC) systems and emergency power generators; and impacts on computers and electronics. A further change was that the content of the original poster on power systems was split between two new posters: one on electricity generation facilities and the other on electricity transmission and distribution networks. This expansion made it possible to incorporate substantial new research in this area (Wardman et al. 2012a). The new series of posters are shown in Figures 6, $7,8,9,10,11,12,13,14,15$. We note that despite telecommunications being a key critical infrastructure sector, we did not consider there to be sufficient documentation of impacts or mitigation guidance to create a robust poster.

\section{Poster content}

Content was derived from the research team's observations of the consequences of volcanic eruptions around the world (summarised in Wilson et al. 2012b). These insights were supplemented by findings from empirical laboratory experiments, such as the vulnerability of highvoltage transmission insulators to flashover from volcanic ash contamination (e.g. Wardman et al. 2012a; 2012b; Wilson et al. 2012b). Poster content was written to be practical, with action-based knowledge. Expert elicitation from AELG members was used to ensure that content was technically correct, relevant and used accurate with terminology (Figure 16). Consultation broadened beyond AELG as required: power generating companies within Bay of Plenty Engineering Lifelines Group contributed to and reviewed 'Advice for Power Plant Operators', the Ministry of Health reviewed 'Advice for Water Supply Managers' and the Civil Aviation Authority reviewed 'Advice for Airport Managers'. Active involvement with the Ministry of Health has also contributed to improved volcanic health impact coordination between volcanic impact scientists and public health professionals. This approach ensured access to the best possible knowledge, facilitated broad participation of relevant organisations, increased awareness of the posters as a resource, and raised the visibility of VISG.

Posters are tailored for individual sectors and reflect each sector's approach to volcanic risk management. Therefore the 'Advice for Airport Managers' poster simply summarises likely impacts and directs airport managers towards national and global planning and response resources, such as the International Civil Aviation Organisation (ICAO) reference guides. The involvement of Air New Zealand Ltd (the major regional airline in New Zealand) and the New Zealand Civil Aviation Authority in designing and reviewing the poster was essential to create a resource aligned with industry standards and suitable for the New Zealand aviation sector.

The restricted space in a poster format enforced concise summaries of impacts and mitigation measures. It was therefore important to be able to refer to further resources and the posters were designed to link with established, authoritative volcanic ash impact information sources. The USGS/GNS volcanic ash impacts website (http://volcanoes.usgs.gov/ash/) and the International Volcanic Health Hazard Network website (www.ivhhn.org) are referred to on nearly all posters, 


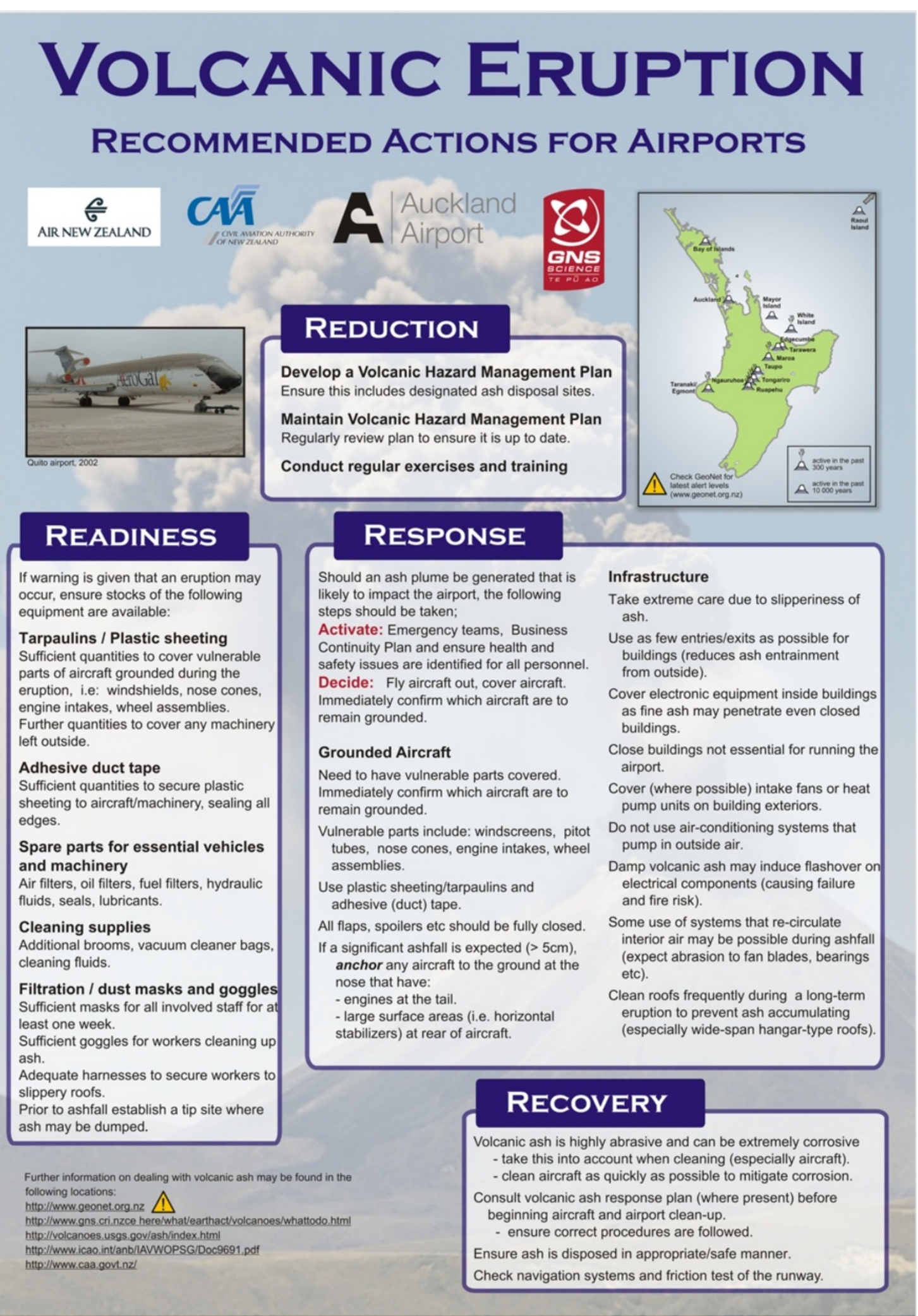

Figure 1 Recommended actions for airports to mitigate ashfall hazard. 


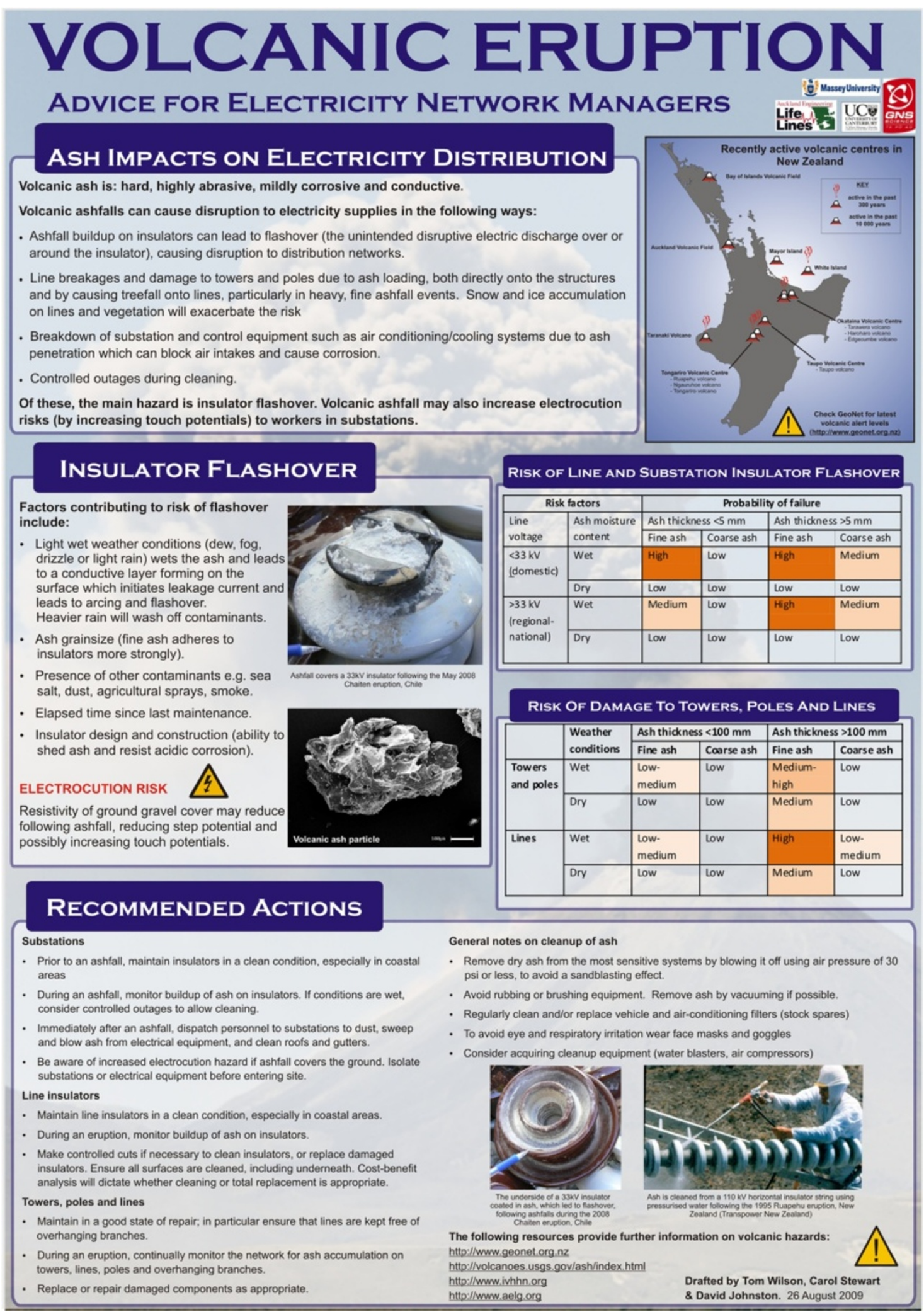

Figure 2 Recommended actions for Electricity Network Managers to mitigate ashfall hazard. 


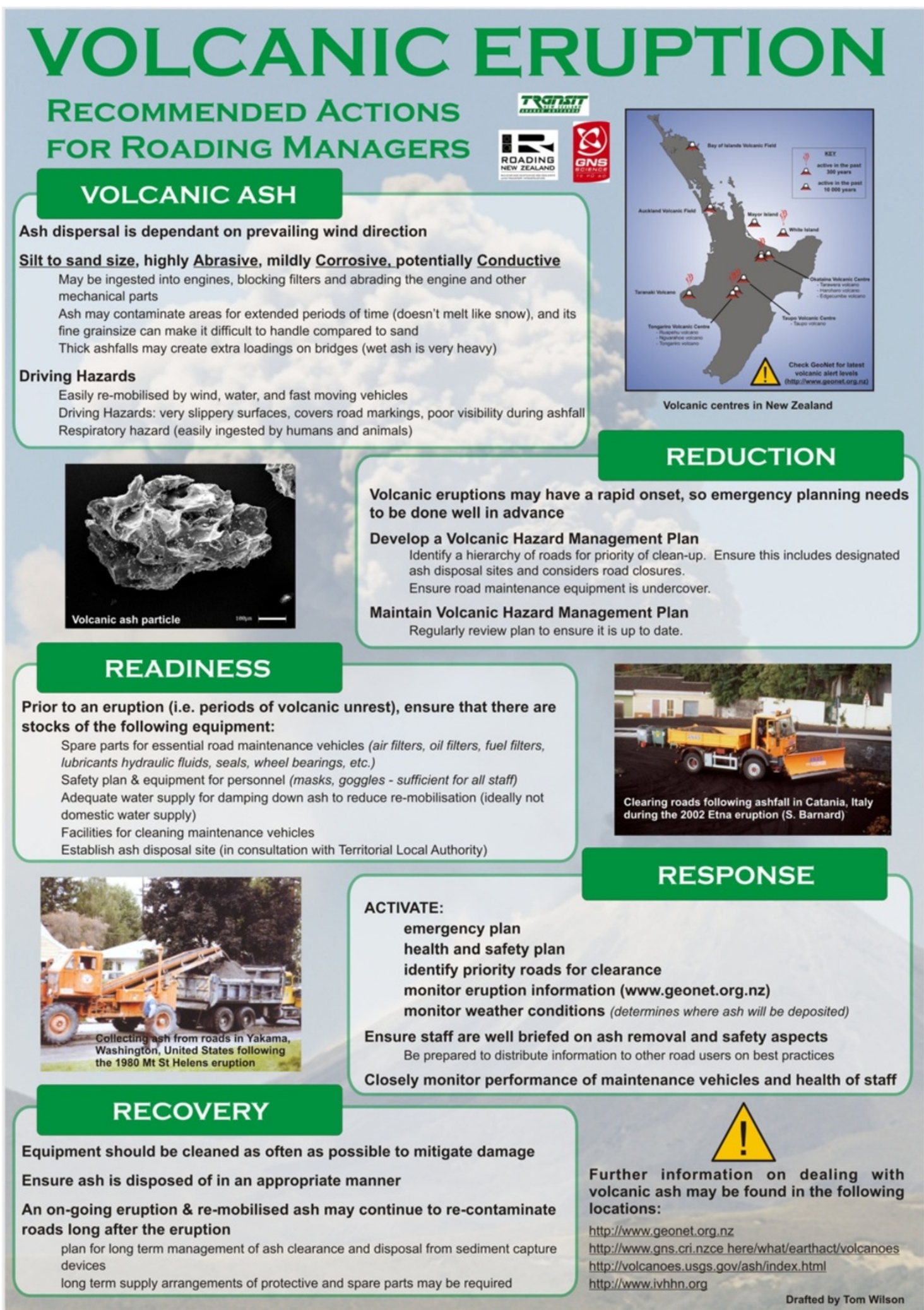

Figure 3 Recommended actions for Road Managers to mitigate ashfall hazard. 


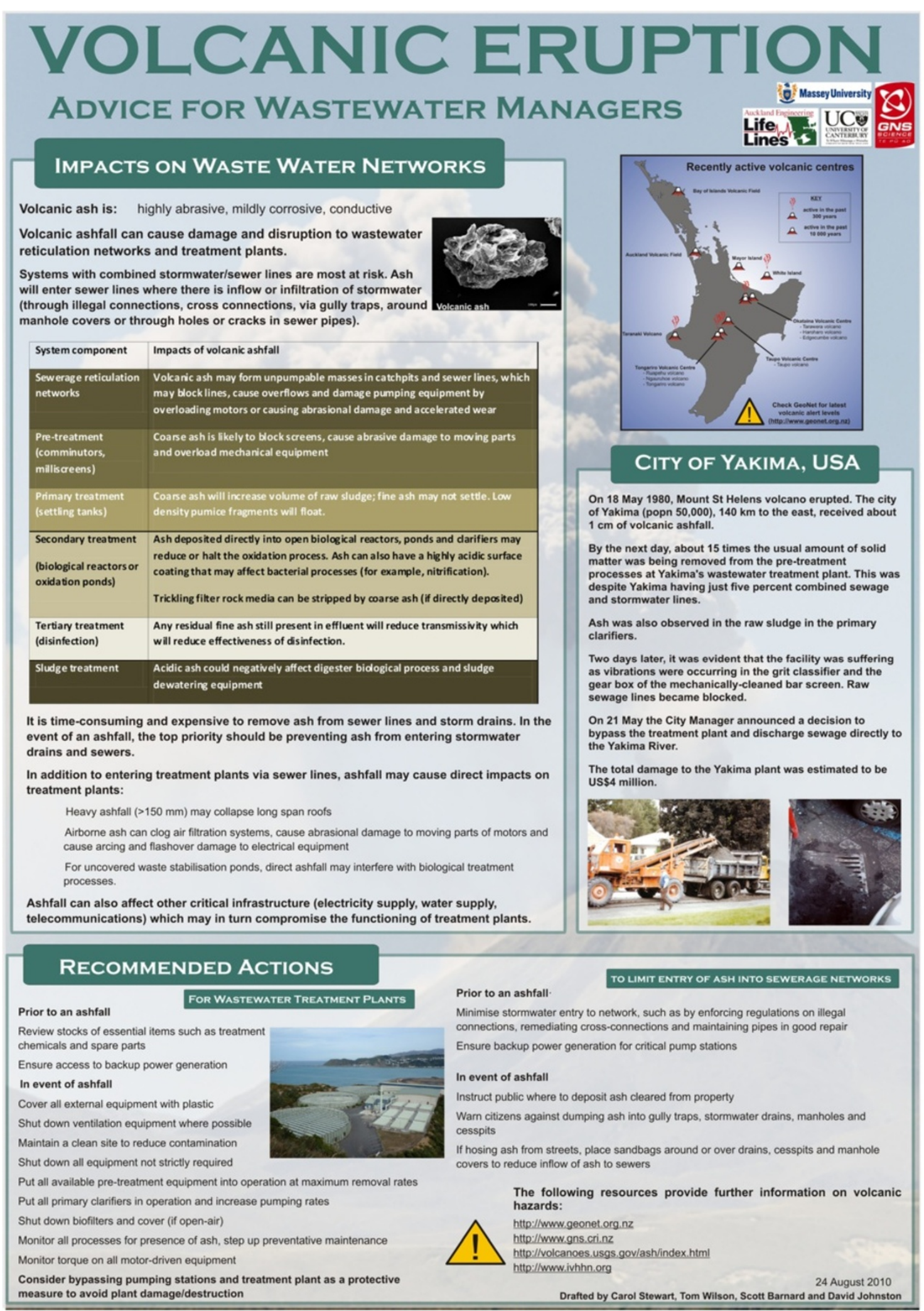

Figure 4 Recommended actions for Water Supply Managers to mitigate ashfall hazard. 


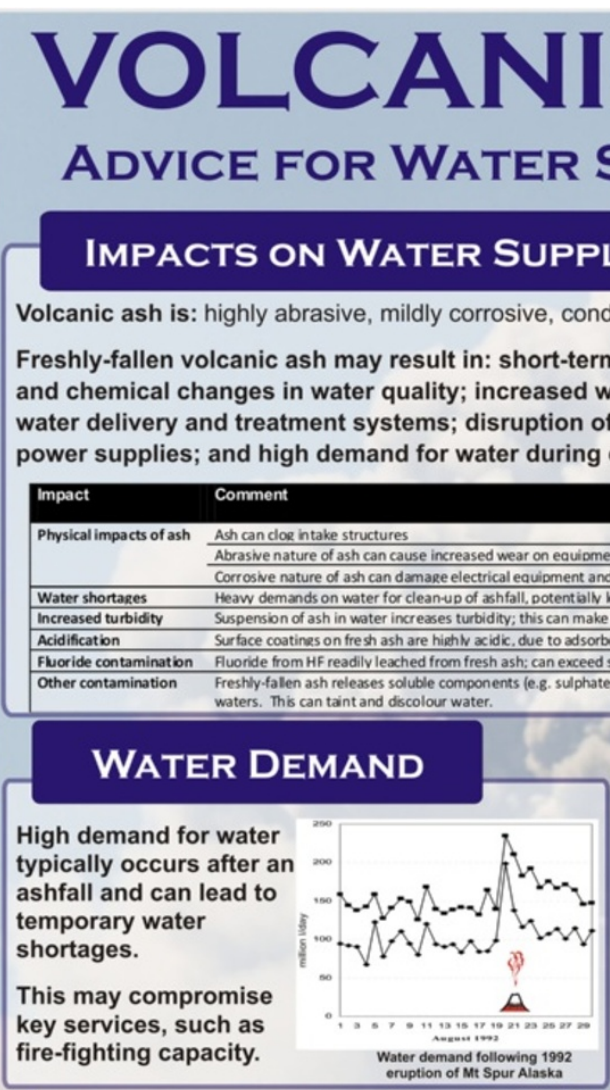

\section{EFFECTS ON EQUIPMENT}

Suspended ash in water can:

- block intake structures

cause abrasional damage and increased wear of equipment

- block filters and clarifiers and generate increased waste

- decrease $\mathrm{pH}$ which can in turn increase plumbosolvency.

Airborne ash particles can:

- clog air filtration systems, causing overheating and engine/motor failure

- abrade and scratch moving parts of equipment and motors - cause arcing and flash-over damage to electrical equipment.

\section{RECOMMENDED ACTIONS}

- conserve water for human consumption

- where possible use alternative, non-potable sources of water for clean-up and fire-

fighting, and encourage clean-up with brooms and shovels rather than hoses

Monitor potentially hazardous components of water ( $\mathrm{pH}$, turbidity, fluoride)

Review stocks of essential items such as spare filters and treatment chemicals

Ensure access to back-up power generation

Take precautions to keep ash out of water supply equipment/plant:

- close water supply intakes before turbidity levels become excessive

- consider adding coagulation/flocculation agent to reduce turbidity

cover filter-beds and clarifiers

- protect other exposed equipment such as electrical control panels

- maintain clean site to reduce contamination.

\section{PUBLIC HEALTH IMPACTS}

Public anxiety about contamination of water supplies is common riss to the public is advised.

1) Hygiene and sanitation problems can arise if water supplies are disrupted following volcanic activity.

High levels of suspended ash (turbidity) can inhibit disinfection of drinking water, which may lead to outbreaks of infectious disease if treatment (e.g. chlorination) is not adjusted accordingly.

3) Elevated fluoride concentrations may be a problem following some types of volcanic eruptions.

Drinking-water Standards for New Zealand 2005 (Revised 2008), Ministry of Health

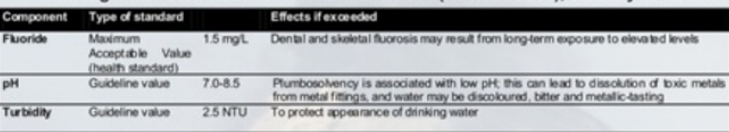

Athorities will analyse volcanic ash composition and advise on the presence of any toxic elements that may pose a health hazard.

in general ashfall is likely to make water undrinkable (metallicasting and discoloured) before it presents health risks.

Figure $\mathbf{5}$ Recommended actions for Waste Water Managers to mitigate ashfall hazard. 


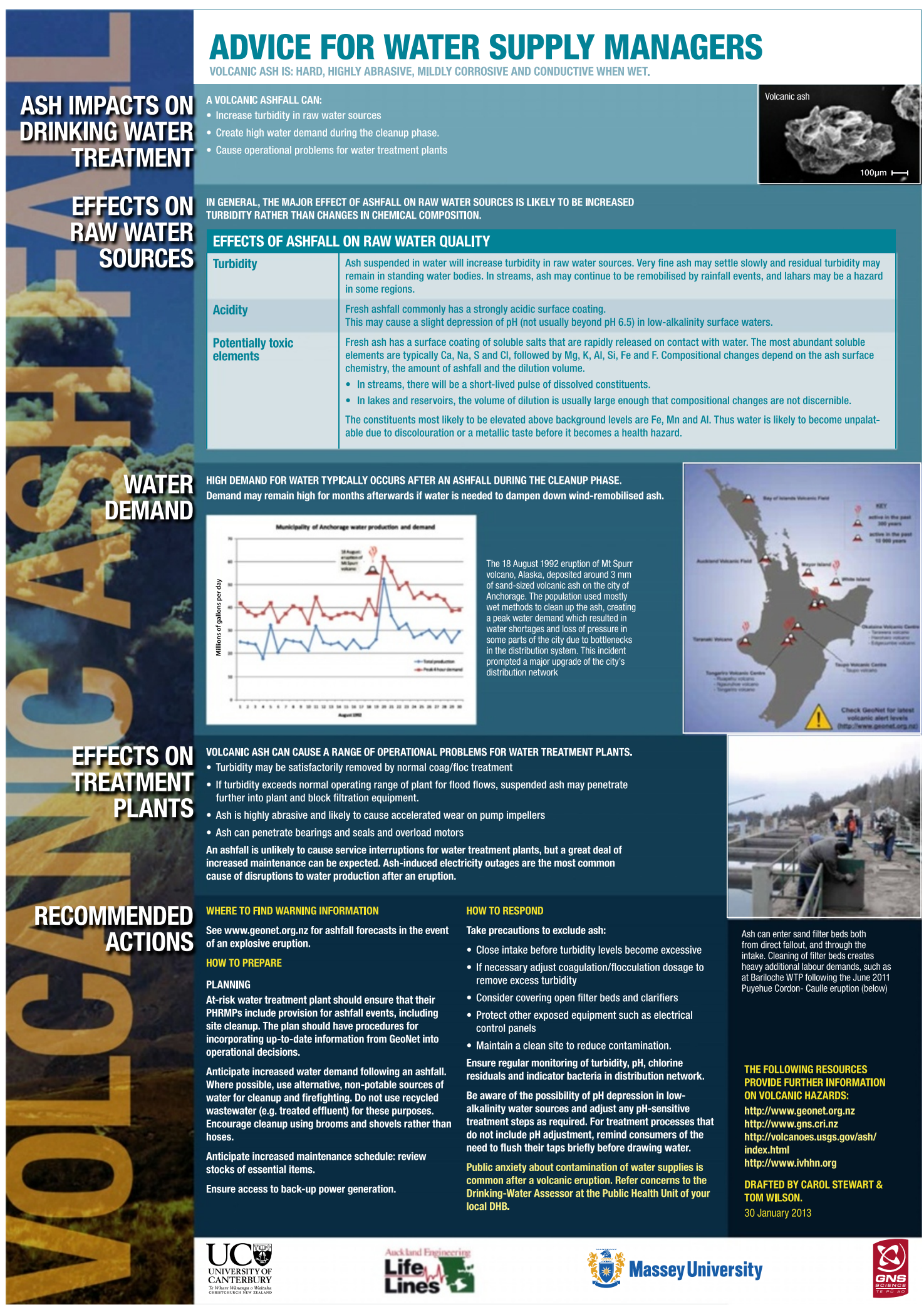

Figure 6 Volcanic Ash: Advice for Water Supply Managers. 

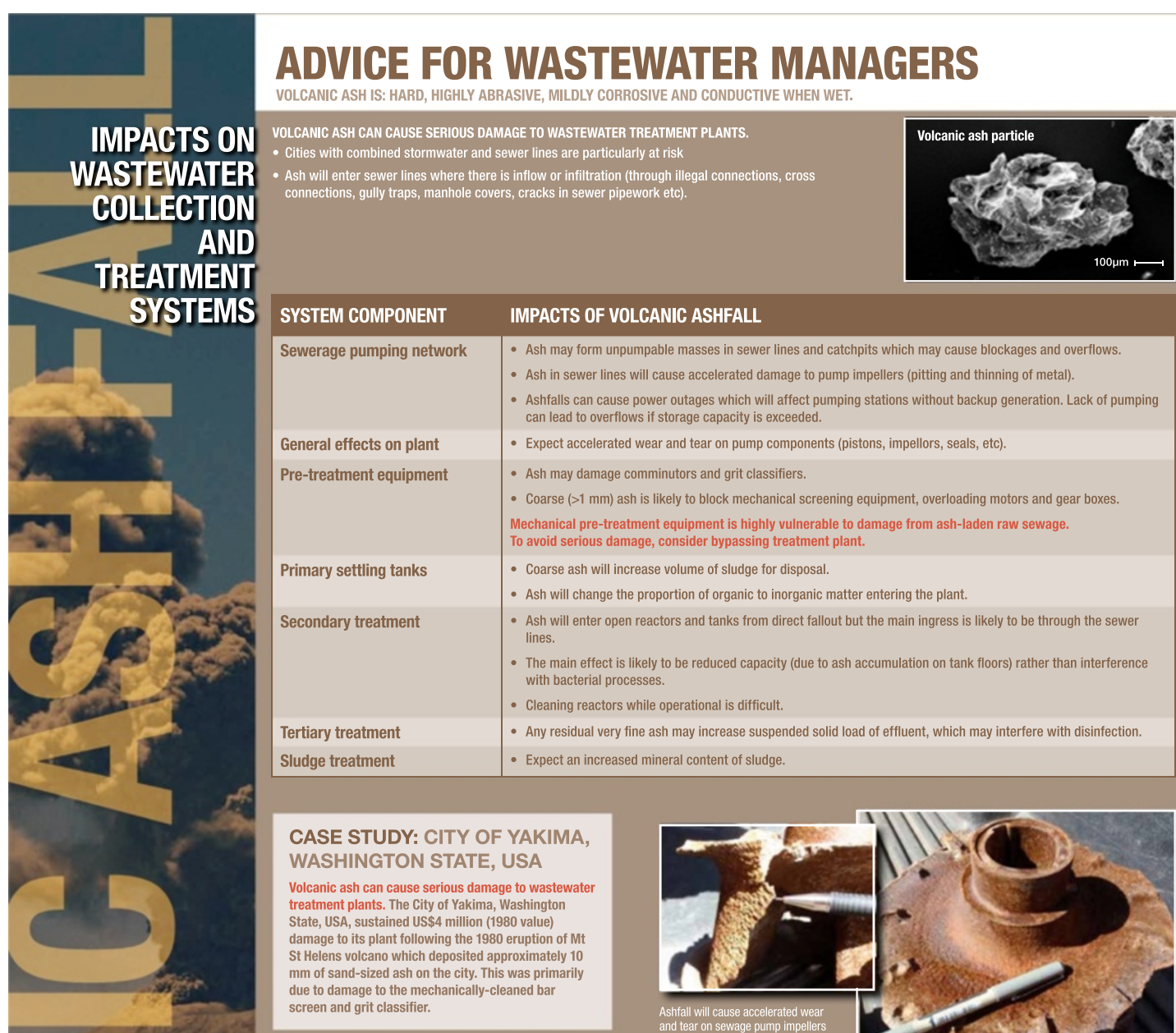

\begin{tabular}{|c|c|}
\hline SYSTEM COMPONENT & IMPACTS OF VOLCANIC ASHFALL \\
\hline Sewerage pumping network & $\begin{array}{l}\text { - Ash may form unpumpable masses in sewer lines and catchpits which may cause blockages and overflows. } \\
\text { - Ash in sewer lines will cause accelerated damage to pump impellers (pitting and thinning of metal). } \\
\text { - Ashfalls can cause power outages which will affect pumping stations without backup generation. Lack of pumping } \\
\text { can lead to overflows if storage capacity is exceeded. }\end{array}$ \\
\hline General effects on plant & - Expect accelerated wear and tear on pump components (pistons, impellors, seals, etc). \\
\hline Pre-treatment equipment & $\begin{array}{l}\text { - Ash may damage comminutors and grit classifiers. } \\
\text { - Coarse }(>1 \mathrm{~mm}) \text { ash is likely to block mechanical screening equipment, overloading motors and gear boxes. } \\
\text { Mechanical pre-treatment equipment is highly vulnerable to damage from ash-laden raw sewage. } \\
\text { To avoid serious damage, consider bypassing treatment plant. }\end{array}$ \\
\hline Primary settling tanks & $\begin{array}{l}\text { - Coarse ash will increase volume of sludge for disposal. } \\
\text { - Ash will change the proportion of organic to inorganic matter entering the plant. }\end{array}$ \\
\hline Secondary treatment & $\begin{array}{l}\text { - Ash will enter open reactors and tanks from direct fallout but the main ingress is likely to be through the sewer } \\
\text { lines. } \\
\text { - The main effect is likely to be reduced capacity (due to ash accumulation on tank floors) rather than interference } \\
\text { with bacterial processes. } \\
\text { - Cleaning reactors while operational is difficult. }\end{array}$ \\
\hline Tertiary treatment & - Any residual very fine ash may increase suspended solid load of effluent, which may interfere with disinfection. \\
\hline Sludge treatment & - Expect an increased mineral content of sludge. \\
\hline
\end{tabular}

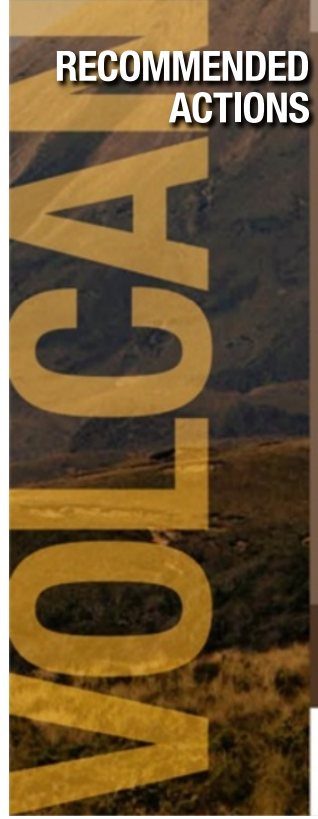

WHERE TO FIND WARNING INFORMATION

See www.geonet.org.nz for ashifall forecasts in the

See www.geonet.org.nz for ash

HOW TO PREPARE

PLANNING

At-risk wastewater treatment plant should develo operational plans for ashifall events, including site

cleanup. Plans should include provision for:

- incorporating up-to-date information from GeoNet

into operational decisions;

- monitoring the presence of ash in raw sewage;

- monitoring torque on motor-driven equipment:

- shutting down non-essential equipment;

- covering exposed equipment such as HVAC

systems, switchboards and electric motors to

protect them from airborne ash;

- limiting the ingress of ash into buildings:

- equipment and labour requirements for sit

cleanup; and

coordination with local and regional emergency

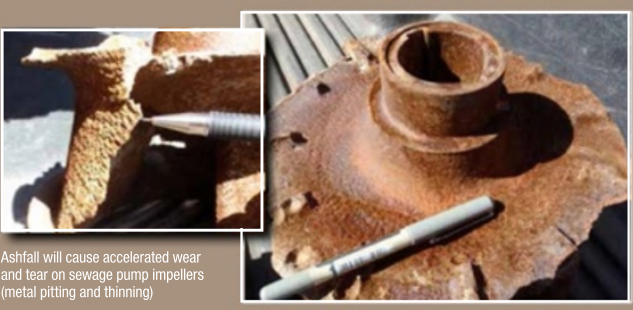

plans.

THE FOLLOWING RESOURCES PROVIDE FURTHER INFORMATION ON VOLCANIC HAZARDS:

http://www.geonet.org.nz $\quad$ http://www.ivhhn.org

Review stocks of essential items, as an ashfall may affect road and air transport.

Ensure access to back-up power generation,

particularly for pumping stations

HOW TO RESPOND

Work with local authorities to limit ingress of ash

into stormwater drains and sewer lines.

Step up preventive maintenance.

Be aware that increased maintenance and site cleanup will create significant additional labour

demands.

Consider bypassing pumping stations and

treatment plant as a protective measure to avoid

strere and cosily damage to pumping and pre-

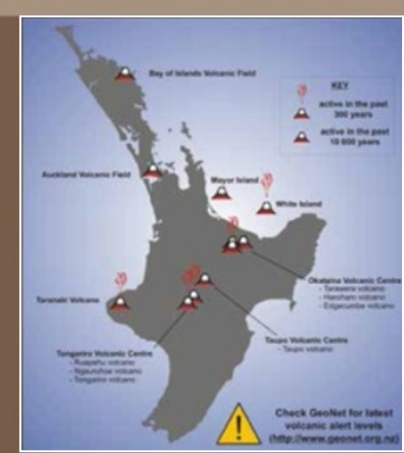

http://www.ivhhn.or

DRAFTED BY TOM WILSON, CAROL STEWART \& JOHNNY WARDMAH.

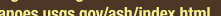

20 January 2013

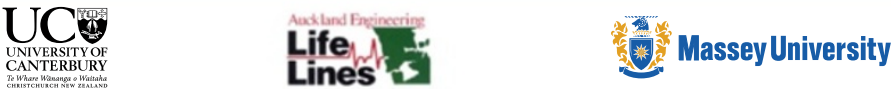

Figure 7 Volcanic Ash: Advice for Wastewater Managers. 

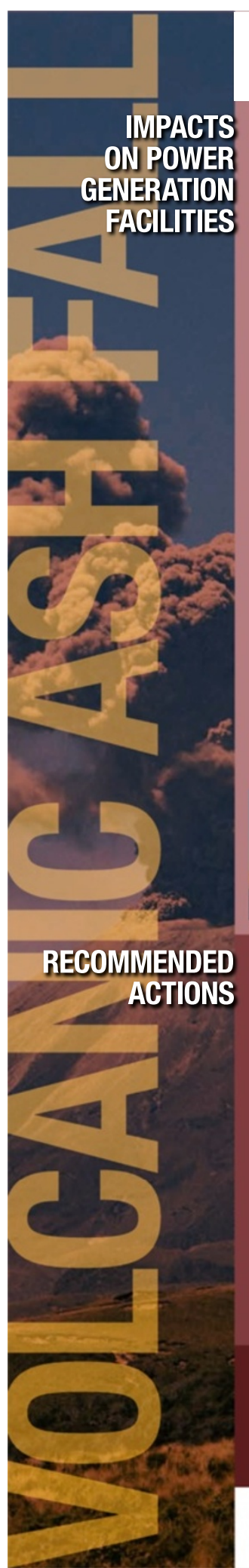

\section{ADVICE FOR POWER PLANT OPERATORS}

VOLCANIC ASH IS: HARD, HIGHLY ABRASIVE, MILDLY CORROSIVE AND CONDUCTIVE WHEN WET.

GENERAL IMPACTS:

- Flashover: Ash contamination of station and line insulators leading to flashover is the most common impact at power plants

See companion poster "Advice for Power Transmission and Distribution System Operators"

- Step/Touch Potential: ash may reduce the resistivity of ground gravel cover, reducing toliable step and touch voltages

- Disruption to Control Systems: ash ingress into heating, ventilation and air-conditioning (HVAC) systems can block intakes leading to reduced performance, and affecting

dependent systems

structures

" Long span, low pitched roofs are typically the most vulnerable "When ash is wet, static loads may increase by up to $100 \%$ - Internal gutters: may block with ash, potentially leading to water ingress to indoor electrical equipment.

HYDROELECTRIC POWER STATIONS

Ash suspended in intake water can cause accelerated wear of hydroelectric turbines (e.g. Ash suspended in intake water can cause accelerated wear of
runner blades, labyrinth seals, cheek plates and wicket gates)

, Hazard depends on volume of ash deposited in catchment, reservoir size, settling rate of ash, abrasiveness of ash

- Ash may also fill rain gauges in climate stations throughout river and reservoir catchments. THERMAL POWER STATIONS

There are few case studies to guide possible impacts or advice.

- Ash may block air intakes for gas turbines and boilers, or sub-aerial condenser systems causing blockages, abrasion and creating cleaning difficulties

"Ash falls have created airborne particle concentrations of up to $9 \mathrm{~g} \mathrm{~m}^{-3}$, several times higher than dust- or sand-storms

- Mechanical seals may be vulnerable to abrasion and corrosion by ash - Fine ash ingested into gas turbines may cause accelerated wear or melt on turbine surfaces (similar to an aircraft turbine)

- Ash may contaminate exposed surface water cooling reservoirs, potentially blocking heatexchange systems.
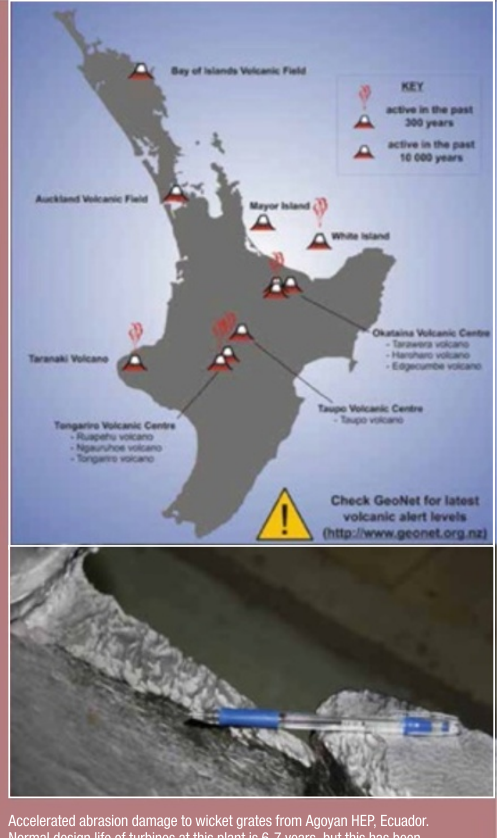
Normal design life of turbines at this plant is $6-7$ years, but this has be fom nearby Tungurahua volcano
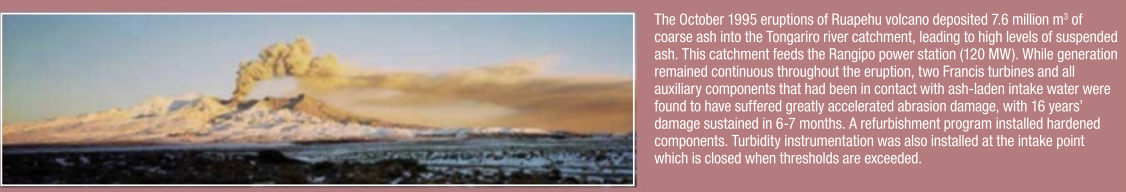

WHERE TO FIND WARNING INFORMATION

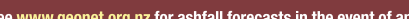

explosive eruption.

HOW TO PREPARE

At-risk power generation facilities should develop operational plans for ash fall

events, including:

- Install turbidity monitoring instrumentation at intake and identify threshold

for intake closure

- Priority schedule for inspecting/cleaning essential sites and components

Site cleanup may be required following an ash fall. Cleanup plans should

include:

"Standardised ash fall clean-up procedures, suitable to your local

conditions and site

"Stock or have access to sufficient supplies and equipment for cleaning; " Clean up and additional maintenance can create significant additional labour and resource demands

"Insulators usually require cleaning. See the companion "Transmission and Distribution "poster and IEEE Std 957 "Guide for Cleaning Insulators" need to be removed, have pre-installed fall arrest anchor points and that safe means of access is identified

MORE INFORMATION

THE FOLLOWING RESOURGES PROVIDE FURTHER INFORMATION ON VOLCANIC HAZARDS:

http://www.geonet.org.nz

http://www.gns.cri.nz

http://volcanoes.usns.gov/ash/index.htm

http://www.ivhhn.org

$\mathrm{UC}$

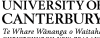

Life

Lines 1

Massey University

Figure 8 Volcanic Ash: Advice for Power Plant Operators. 

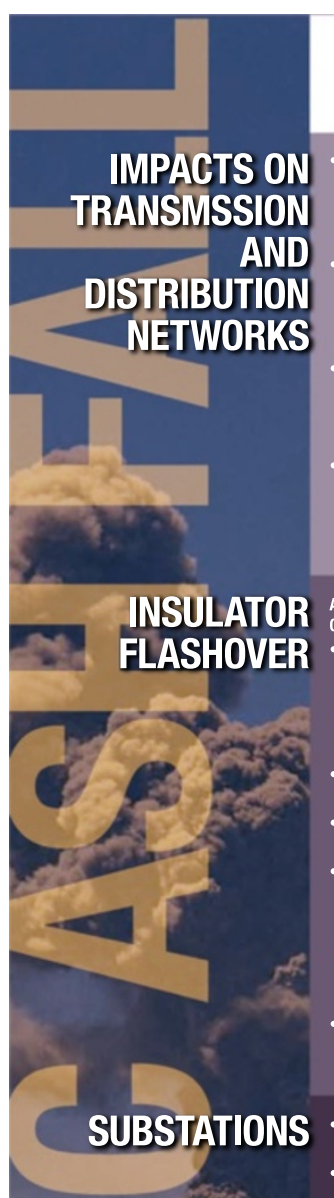

BEEOMMNENDED ACTIONS

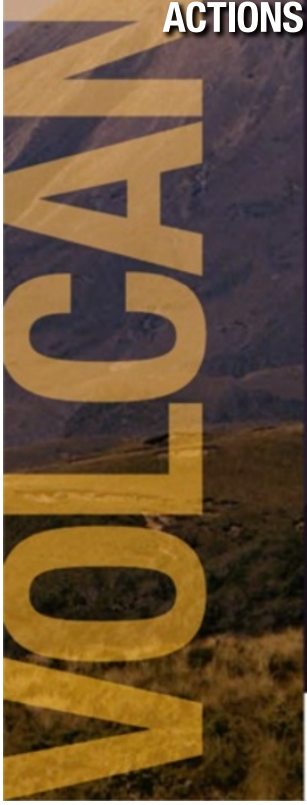

ADVICE FOR POWER TRANSMISSION AND DISTRIBUTION SYSTEM OPERATORS

VOLCANIC ASH IS: HARD, HIGHLY ABRASIVE, MILDLY CORROSIVE AND CONDUCTIVE WHEN WET.

- Insulator Flashover : Ash contamination of station and line insulators can lead to filashover.

Flashover may occur with $<3 \mathrm{~mm}$ of ash fall provided a significant portion of the

insulator creepage distance $(>50 \%)$ is covered in wet ash;

" This is the most common and widespread impact;

Loading Damage : ash accumulation may overload lines, weak poles and light structures,

and cause additional tree-fall onto lines. Precipitation will exacerbate the risk;

Typically occurs with $>100 \mathrm{~mm}$ ash accumulation;

》I Induced tree fall from ash load may occur with thicknesses $>10 \mathrm{~mm}$

Disruption to Control Systems : ash ingress into heating, ventilation and air-condilitioning (HVAC) systems can block intakes leading to reduced performance, and affecting

„Possible during any thickness of ash fall;

- Earth Potential Rise : Ash may reduce the resistivity of substation ground gravel cover,

reducing tolerable step and touch voltages;

"Not observed, but theoretically possible.

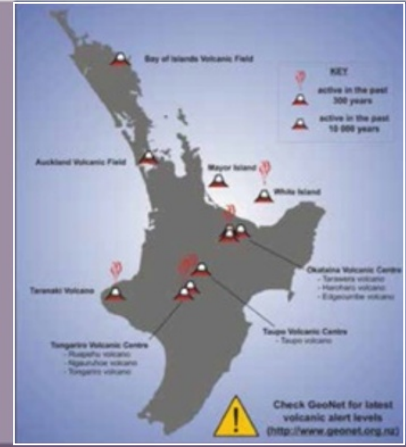

ASH RESISTIVITY AND ASH COVERAGE OF THE PPOTECTED LEAKACE (CPEEPACE) DISTANCE OF INSULATORS ARE THE PRIMARY CONTROLS ON FLASHOVER LIKELIHODD

- Dry ash is highly resistive. Wet ash can be highly conductive

" Light precipitation (dew, fog, drizzle or light rain) wets ash which initiates a leakage current, leading to flashover.

Heavy rain will wash off contaminants, and high winds will clean non-cemented dry ash from insulators.

- Flashover may occur with $<3 \mathrm{~mm}$ of ash fall provided a significant portion of the insulator creepage distance (e.g. $>50 \%$ ) is covered in wet ash

- Ash adherence is often variable, ranging from non-binding to cementing. Fine grained ash $(<0.5 \mathrm{~mm})$ typically adheres and cements to insulators more readily.

- Insulator profile, orientation and material will influence its ability to shed or retain ash. " Material: Non-ceramic (e.g. polymer) insulators generally outperform ceramic designs and have smaller shed diameters which appear to shed ash more effectively

"Design: Anti-pollution insulator designs can increase performance "Orientation: evidence suggests suspension (vertical) insulator strings are generally more vulnerable, but this depends on the direction of falling ash and weather condition - Overseas experience suggests over-insulation (increasing creepage distance) and dimensioning of high-voltage insulators for use in polluted conditions'.

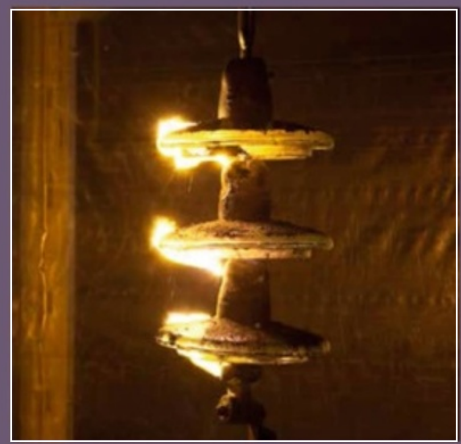

$3 \mathrm{~mm}$ of ash fall cover on a glass insulator string inducing a flashover. Note
how the current is tracking through the volcanic ash covered insulator surface

Specialist inspection and cleaning procedures may be required for substation

- Specialist inspection and cleaning procedures may be required for
insulators, power transformer HVAC systems and control systems;

- Ash may reduce the resistivity of substation ground gravel cover, reducing

tolerable step and touch voltage

WHERE TO FIND WARNING INFORMATION

see www.geonet.org.nz for ashfall forecasts in the event of an explosive

eruption. www.geonet.org.nz

HOW TO PREPARE

- Cleaning ash contaminated sites and components, especially insulators, is commonly required after an ash fall. Ensure availability of both live-line and de-energised cleanup plans which include:

» Priority schedule for inspecting/cleaning essential sites and lines

»Standardised ash fall clean-up procedures

"Ready access to cleaning supplies and equipment (air compressors, water-blasters, PPT gear, vehicle air filters,)

- Cleaning Guidance: see IEEE Std 957 'Guide for Gleaning Insulators'.

Experience suggests:

" Ensure all insulator surfaces are cleaned, including undersides of

weathersheds

Insulator cleaning method will be determined by strength of ash adherence:

- Field crews should use safe operating procedures when operating in an 'ashy' ash hazards

Coordinate with local, regional and national emergency planning, as appropriate

MORE INFORMATION

THE FOLLOWING RESOURCES PROVIDE FURTHER INFORMATION ON VOLCANIC

HAZARDS:

- Initiate priority schedule for inspection and cleaning. Increased inspection and preventive maintenance may be prudent.

- A proactive communication campaign for customers/public covering your response, expected outages/restoration times and recommended actions aids awareness and good will

Advise customers not to clean electrical equipment and to be carefu when using hoses near electrical equipment.
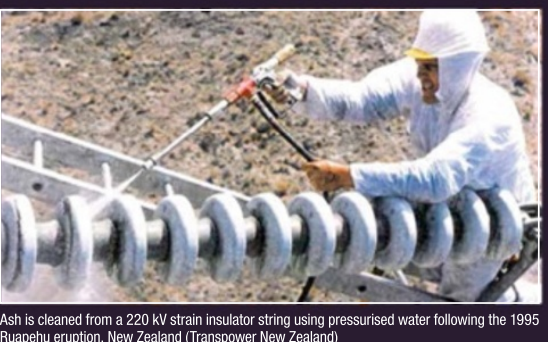

Ruapehu eruption, New Zealand (Transpower New Zealand)

DRAFTED BY TOM WILSON, CAROL STEWART AND JOHNNY WARDMAN. 28 May 2013

http://www.geonet.org.nz

http://www.gns.cri.nz

the:/volcanoes usas gov/ash/index.htm/

http://www.ivhhn.org

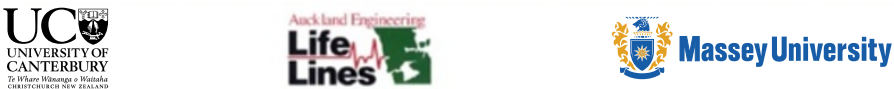

Figure 9 Volcanic Ash: Advice for Power Transmission and Distribution System Operators. 


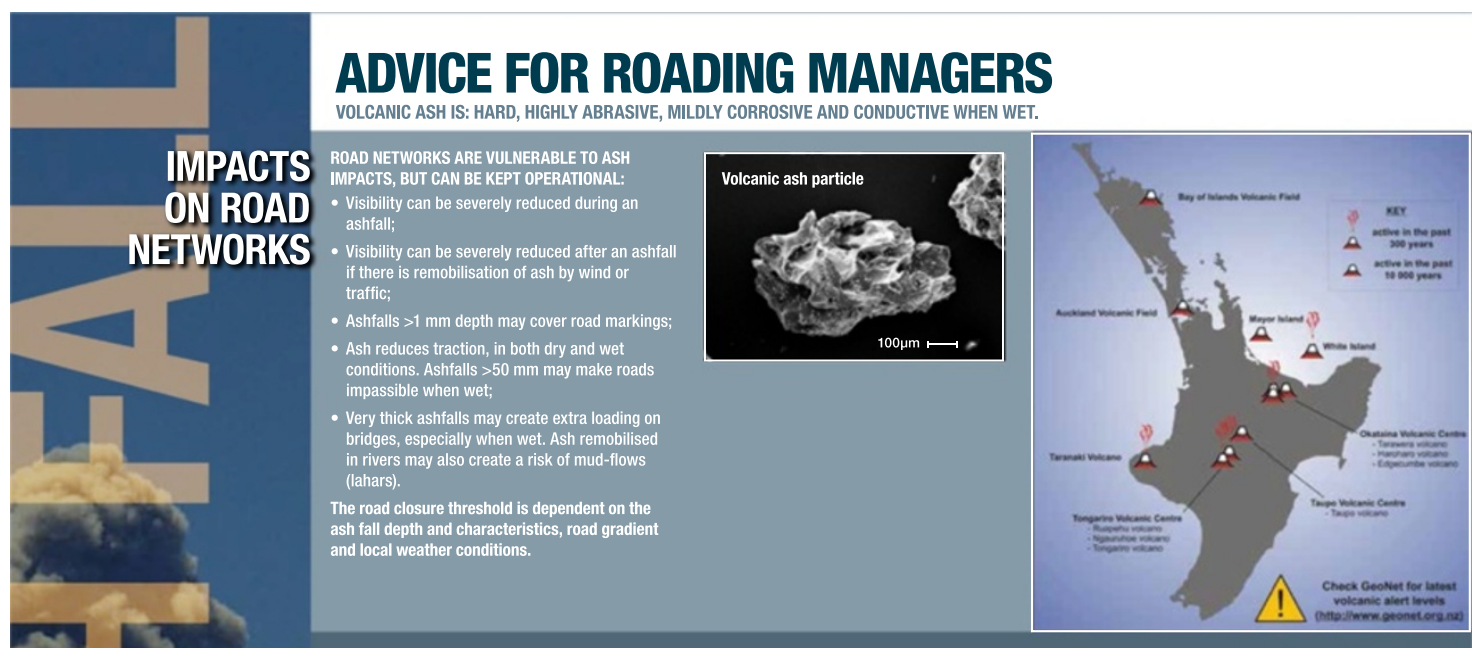

\section{DAMAGE TO ASH MaY CAUSE A RAMGE OF DAMAGE TO VEHICLLS:}

VEHICLES: clogsing of a ir and oif filters

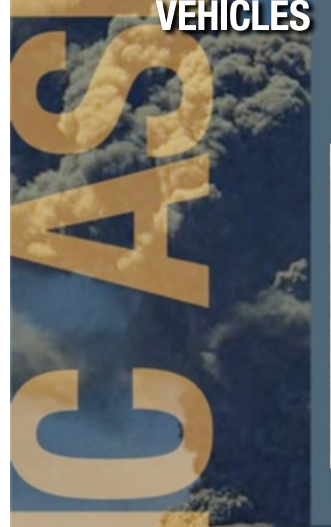

- abrasion of moving engine parts

- corrosion of exposed metal surfaces.

CASE STUDY FUTALEUFU, CHILE

- abrasion damage to paintwork

The May 2008 eruption of Chaiten volcano, Chile, deposited $30-40 \mathrm{~mm}$ of

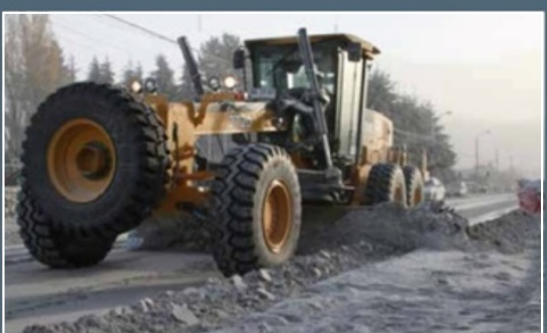

Clearing main road in the town of Futaleufu, Chile

fine-grained rhyolitic ashfall on the town of Futaleufu, Chile.

BEEOMMMENDED

WHERE TO FIND WARNING INFORMATION

ACTIONS

www geonetorgent an explosire

eruption.

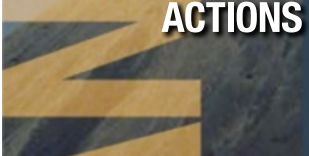

HOW TO PREPARE

PLANNING

At-risk regions should develop operational plans for volcanic ashfall. These

should include:

- Identification of a hierarchy of roads for priority of cleanup

- Road closure protocols:

- Equipment and labour requirements for cleanup operations;

- Identification of ash disposal sites:

- Coordination of plans with local and regional emergency plans.

HOW TO RESPOND

IF OPERATING MACHINERY OR VEHICLES:

Check, clean and replace air and oil filters regularly.

Wash windscreens, painted and metals surfaces rather than wiping, to avoid

abrasion damage. Avoid using windscreen wipers.

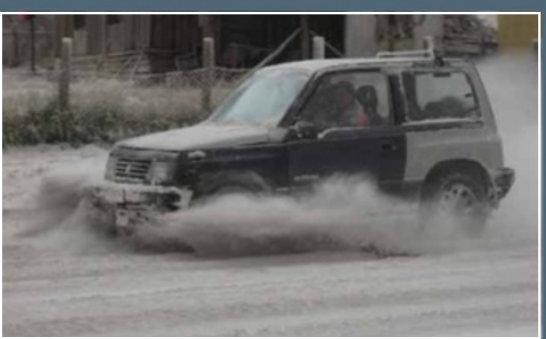

Apply lubricant/grease more frequently and check for wear.

Driving in approximately $10 \mathrm{~mm}$ ashfall, near Futaleufu.

MANAGEMENT OF ROADING NETWORK

Advise public to reduce non-essential travel.

If ashfalls are causing traction or visibility problems, implement safety measures such as reduced speed advisories, one-way rules, headlights on and ensuring a safe following distance.

CLEANUP

Ash cleanup can be expensive and time-consuming. It can be complicated by ongoing voicanic activity producing further ashfalls, or by wind remobilisation of deposited ash. See 'Advice for ash cleanup' poster in this series for more specific guidance. General principles are to:

- Clean roads as soon as possible, to reduce remobilisation problems and to make safe

- In urban areas, take steps to prevent ash from entering storm drains or sewers, as it can block underground pipework and be extremely difficult to remove, and can cause severe damage to wastewater treatment plants;

- Ensure that field crews wear appropriate protective clothing (long-sleeved clothing, approved face masks and goggles) when operating in ashy

Dispose of ash in appropriate sites;

Communicate work schedule with other stakeholders and the public.

THE FOLLOWING RESOURCES PROVIDE FURTHER INFORMATION ON VOLCANIC HAZARDS: http://www.geonet.org.nz

http://www.gns.cri.nz

http://www.ivhhn.org

DRAFTED BY TOM WILSON, CAROL STEWART GRANT WILSON AND MARLENE VILLEMURE.

7 February 2013

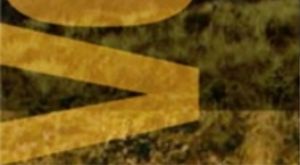

\section{$\mathrm{UC}$}

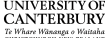

Life

登善 Massey University

Figure 10 Volcanic Ash: Advice for Roading Managers. 


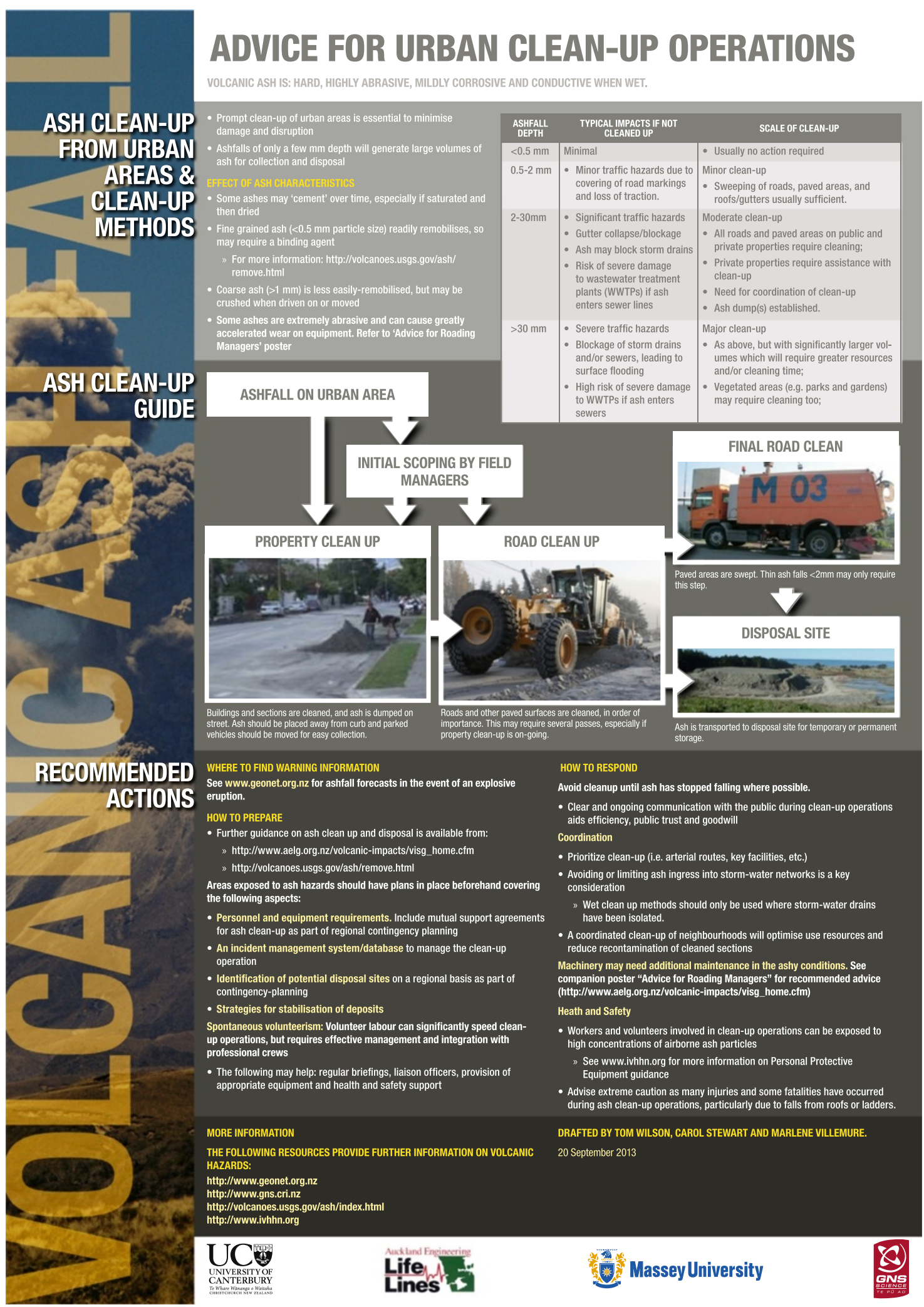

Figure 11 Volcanic Ash: Advice for Urban Clean-up Operations. 


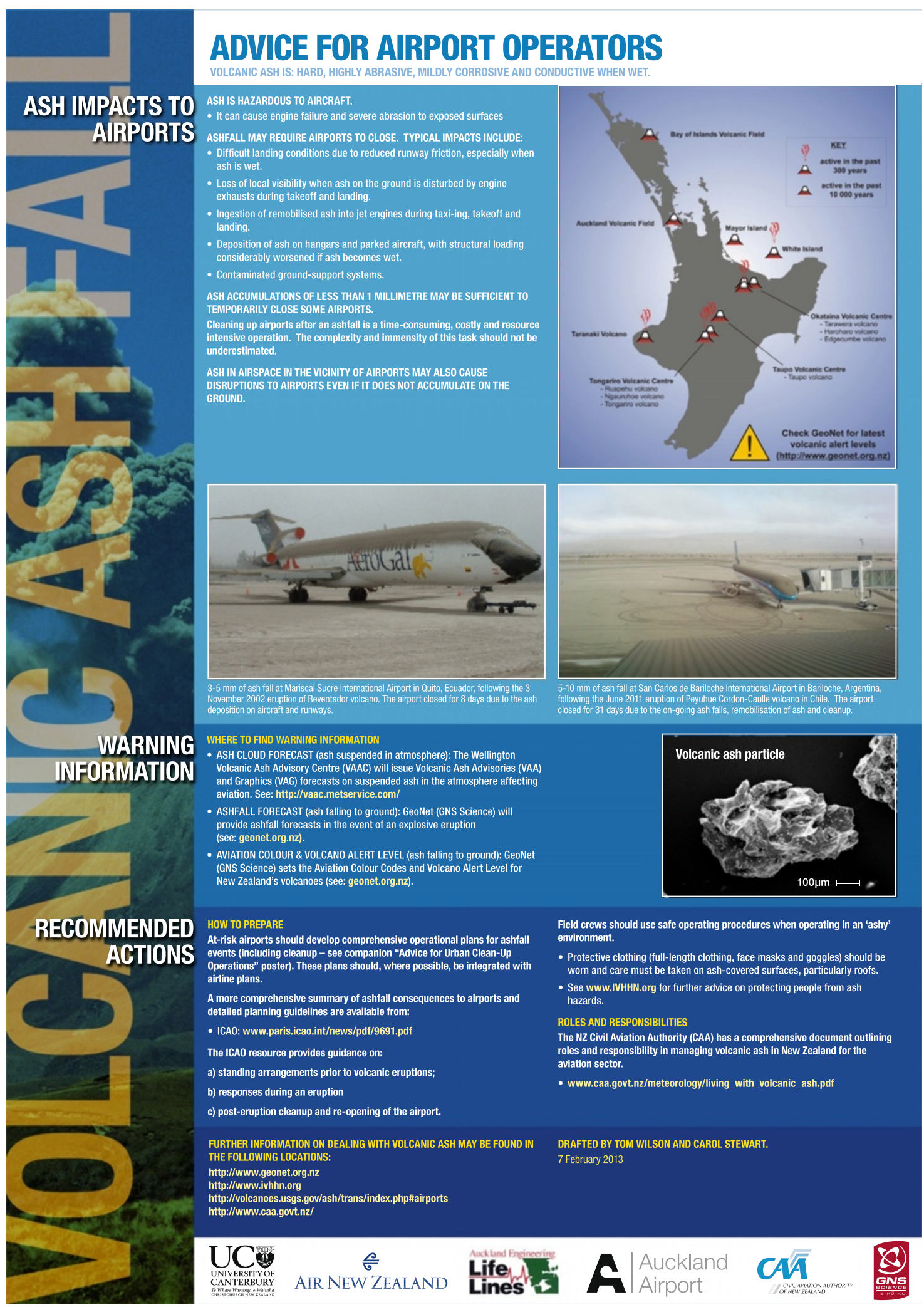

Figure 12 Volcanic Ash: Advice for Airport Operators. 

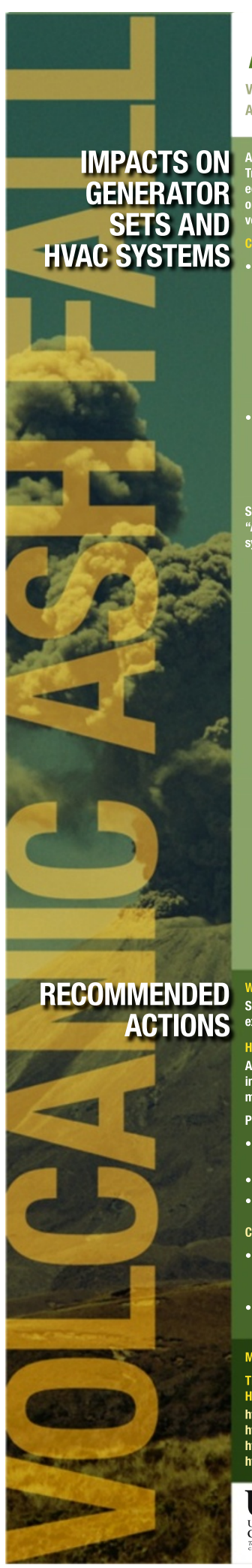

.

explosive eruption.

HOW TO PREPARE

At-risk facilities should develop operational plans for managing ash fall events, including a priority schedule and standardised procedures for inspecting/ including a priority sch:
maintaining/cleaning:

Physical mitigation options:

Install hoods over air intake to reduce direct ash ingestion (see bottom left figure)

- Add temporary filtration to external air intakes, monitor and replace as needed

- Seal or cover sensitive equipment, such as external fuel valves and switches

Cleaning Guidance:

- Vacuum or gently ( $30 \mathrm{psi}$ or less) blow away excess ash from air intakes or condensers, then wipe down with a cloth. Air filters should be removed before cleaning

Wet methods for ash cleanup are not recommended, as they may promote clogging of radiator fins, or cause short-circuits

MORE INFORMATION

THE FOLLOWING RESOURCES PROVIDE FURTHER INFORMATION ON VOLCANIC AAZARDS:

http://www.geonet.org.nz

http://www.gns.cri.nz

usgs.gov/ash/index.htm!

ittp://www.ivhhn.org

\section{UCe}

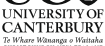

年

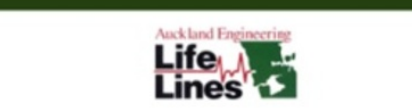

Lines

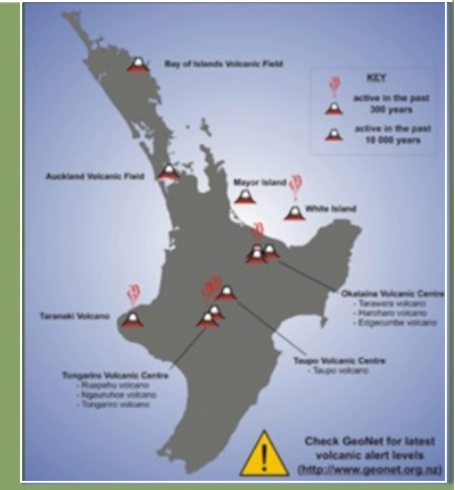

Figure 13 Volcanic Ash: Advice for Facilities Managers: GenSets and HVAC. 


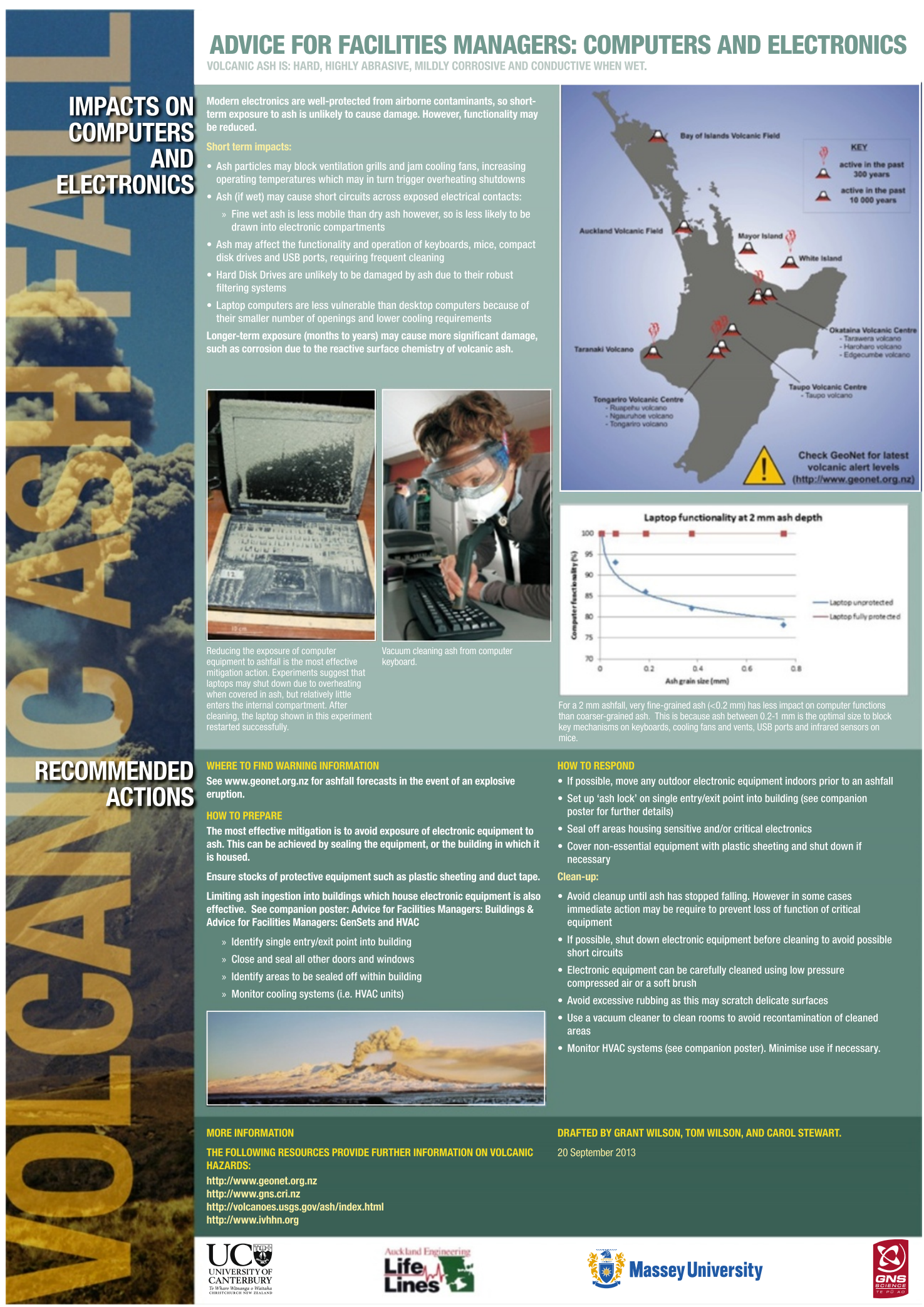

Figure 14 Volcanic Ash: Advice for Facilities Managers: Computers And Electronics. 


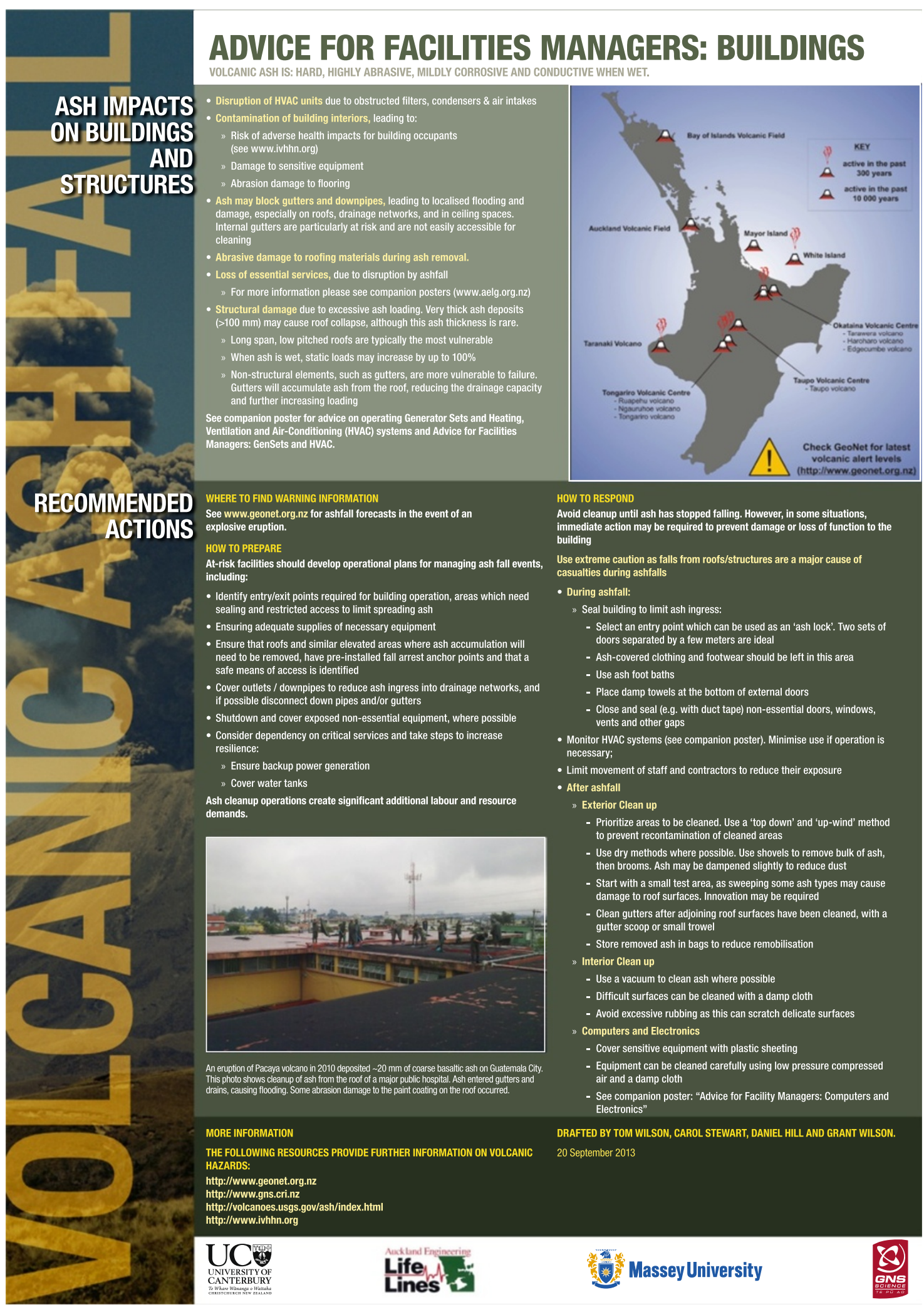

Figure 15 Volcanic Ash: Advice for Facilities Managers: Buildings. 


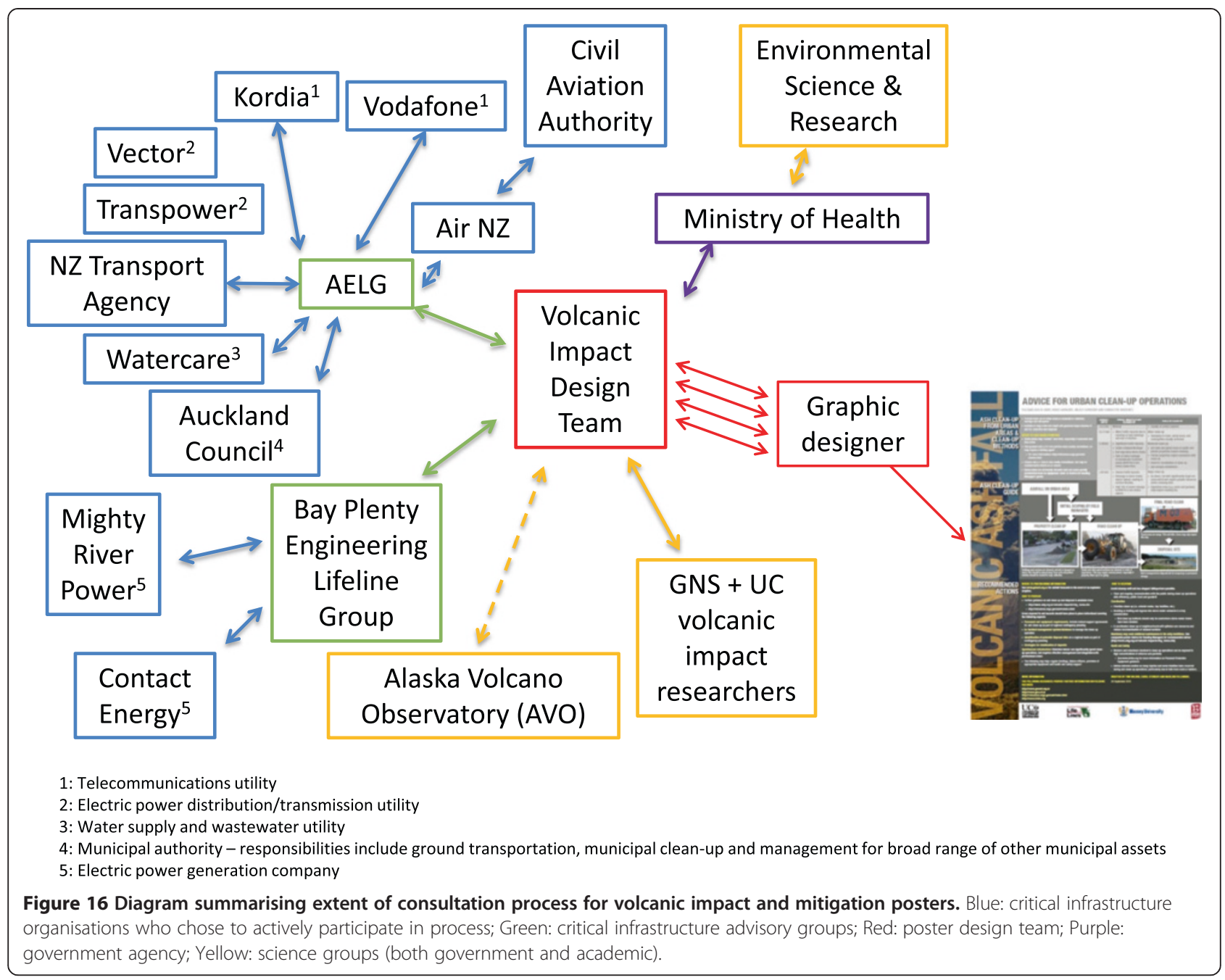

depending on topic and intended audience. Sector-specific resources are provided where available, such as the ICAO Manual on Volcanic Ash, Radioactive Material and Toxic Chemical Clouds (ICAO 2007) referenced on the poster on 'Advice for Airport Managers'.

\section{Design}

The posters are designed as fact sheets which refer the specialist audience to specific information, such as further web-based resources or industry standards where appropriate. Language, terminology and graphics used on the posters are designed primarily for the target audience of New Zealand critical infrastructure managers. Design elements of the posters are described in Figure 17.

\section{Review process}

The posters underwent a two-stage review process. Initially they were reviewed by a team of eight scientists within the VISG project team, then submitted to a technical sub-group of the AELG or other appropriate organisations (Figure 16), typically including engineers, risk managers and business continuity advisors. Their feedback was used to revise the posters. This process was repeated as required, with up to five iterations in some cases. Posters were also reviewed by colleagues from the Alaska Volcano Observatory, who have extensive operational experience in responding to ashproducing eruptions and interacting with affected sectors before, during and after ashfall events. This provided a valuable external perspective.

\section{Dissemination}

Once finalised, the updated Series 2 posters were distributed to all AELG members, to the New Zealand National Engineering Lifelines Committee for national distribution, and also hosted on the AELG and GNS Science websites as an open access resource (http://www.aelg.org. nz/volcanic-impacts/visg-projects/; http://www.gns.cri. nz/Home/Learning/Science-Topics/Volcanoes/Eruption- 


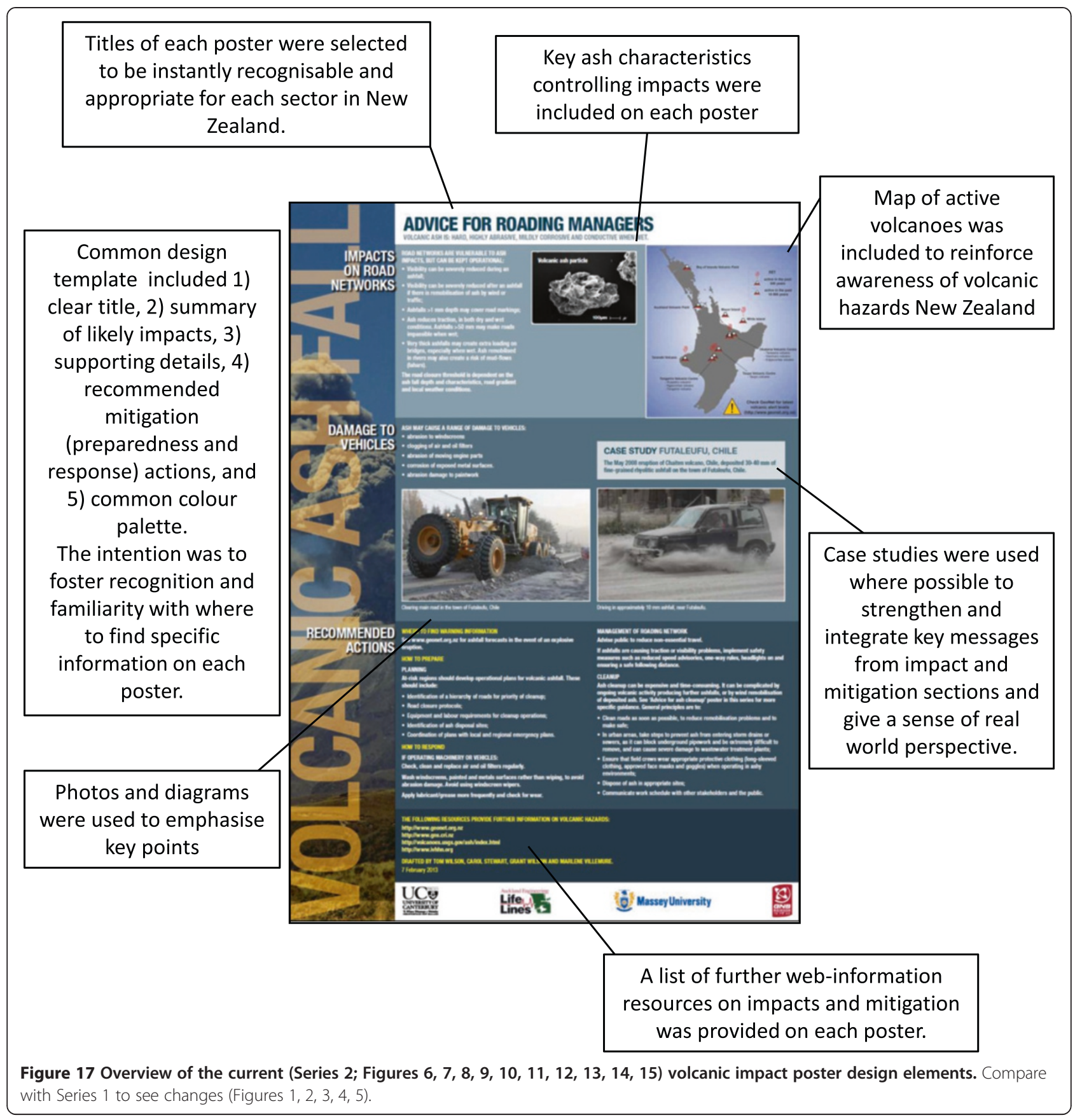

What-to-do/Ash-Impact-Posters). Public outreach talks and briefings by GNS Science staff in New Zealand, which regularly include briefings to regional engineering lifeline groups, routinely promote awareness of the posters, along with other preparedness and mitigation resources. An annual volcanic hazard short-course for infrastructure and emergency managers also uses the posters during exercises. They are also used in university teaching for scenario-based role-play simulations. Series 1 posters were also widely disseminated and utilised during the $2012 \mathrm{Te}$ Maari eruption from Tongariro volcano.
The suite of posters has also been shared internationally, via distribution by the IAVCEI Cities and Volcanoes Commission's Volcanic Ash Impacts Working Group and will be hosted on the USGS Volcanic Ash Impacts Website (http://volcanoes.usgs.gov/ash/index.html) as a resource for the global community.

\section{Posters in action - Esquel case study}

A practical test of the posters' utility occurred during the May 2008 eruption of Volcan Chaitén, Chile (Stewart et al. 2009). In early May 2008 widespread ashfall from the 
explosive rhyolitic eruption was distributed by the prevailing westerly winds over Argentina. The city of Esquel (pop. 35,000), located $110 \mathrm{~km}$ east of the volcano in Chubut province, Northern Patagonia, received approximately $5 \mathrm{~mm}$ of fine ash on the morning of 5 May (Figure 18A). Public authorities were immediately concerned about contamination of the city's water supply as residents reported a 'strong metallic taste' in the drinking water.

The water sources for the city are primarily groundwater and thus are relatively resilient to ashfall contamination. However, there is a point of vulnerability where the water is delivered to the treatment plant along the open, concrete-lined $2.3 \mathrm{~km}$-long Canal de Faldeo (Figure 18B).

The water supply authority did not have any knowledge of potential impacts of an ashfall on the water supply. In their search for information they contacted a member of our research team (CS) who had authored a review of the subject (Stewart et al. 2006). She provided advice, in collaboration with a local university, on an appropriate water sampling and monitoring regime and interpretation of ashfall leachate data. Using the poster "Advice for water supply managers" (Figures 1, 2, 3, 4, 5), she also provided guidance on impacts and mitigation strategies. Water sampling showed that levels of sulphate and dissolved iron and aluminium were higher in the Canal de Faldeo than the raw water source, and to a lesser extent, in treated drinking water (Stewart et al. 2009). These elevated levels were sufficient to produce a noticeable taste in the final drinking water but remained well below Argentinian drinking water standards (see Stewart et al. 2009). The water authority was thus able to reassure the public that ashfall contamination of the water source did not pose a public health risk.

Two-way exchange of information between the poster design team and the water authority was critical for ground-truthing and refining the management advice on the posters. Our predictions were that the primary impacts of the ashfall would be an increase in raw water turbidity and that water demand would increase as residents cleared ash from their properties. These both proved to be the case. Local authorities also noted the value of the poster's advice to communicate information to the public in a timely and transparent manner as the metallic taste in the water had caused some anxiety about contamination of the water supply.

\section{Internationalising posters?}

The case study above illustrates that these posters may be useful tools during an eruption crisis beyond the New Zealand context for which they were designed. The technical and engineering content of the posters was based on findings of ashfall impact assessment trips, to an extensive range of volcanically-active countries (Table 1, Volcanic impacts research group). Thus, the advice given is applicable to infrastructure not just in New Zealand (which has highly-modernised infrastructure) but in other, less-developed, settings. For example, the 'Advice for Wastewater Managers' poster (Figure 7) describes ashfall impacts on individual system components, so that individual treatment facilities can select relevant components. Similarly, many components of infrastructure systems such as pumping equipment, HVAC units and engine components are universal thus the mitigation advice given is applicable.

However, we note that the emergency management content of the posters is specific to New Zealand. This includes aspects such as where to find warning information in the event of an eruption, and (for the 'Advice for Airport Managers' poster) contact details for the local Volcanic Ash Advisory Centre (VAAC).

\section{Summary}

This paper describes a collaborative process used to create a suite of ten informational posters intended to improve

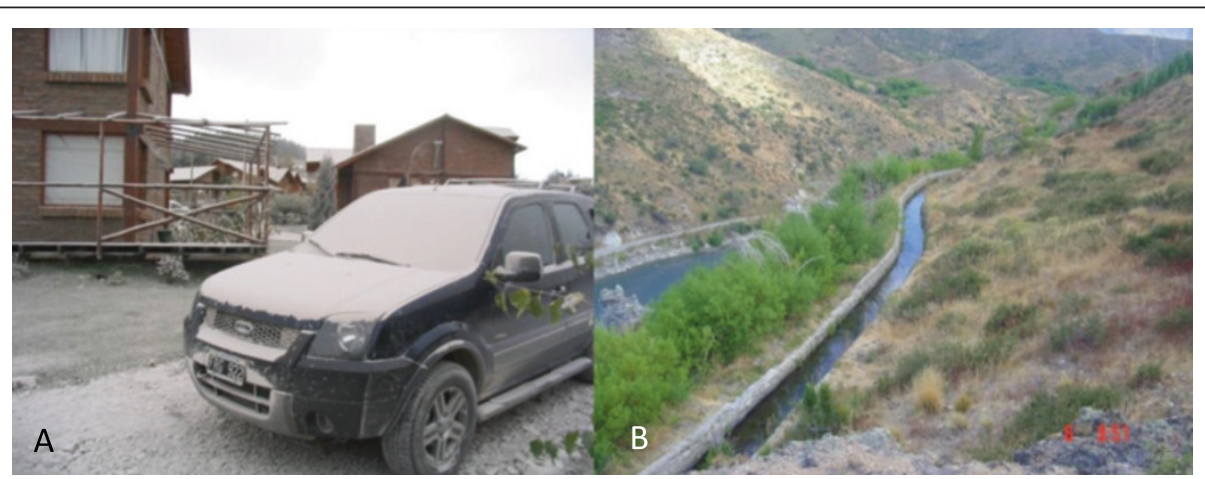

Figure 18 Chaiten ashfall in Esquel, Argentina. A) Approximately $5 \mathrm{~mm}$ of fine-grained rhyolitic ash fell in the town on 5 May 2008; B) The Canal de Faldeo open water supply line for Esquel, Argentina. 
the resilience of critical infrastructure organisations to volcanic ashfall hazards. Key features of this process were:

- a collaborative partnership between critical infrastructure managers and relevant government agencies with volcanic impact scientists;

- consultation and review phases; and

- translation of volcanic impact research into practical management tools.

In addition to producing the posters, which are a unique global resource, the process has further enhanced and grown networks between volcanic impact scientists/agencies and critical infrastructure organisations. We note that our work has been developed in a New Zealand context and thus has relied heavily on the highly networked VISG and AELG structures, and existing risk management culture. Whilst the posters have utility beyond New Zealand, as demonstrated by the Chaitén case study, we propose that this development process may be a useful model for strengthening volcanic risk resilience in other settings.

\section{Competing interests}

The authors declare that they have no competing interests.

\section{Authors' contributions}

TW and CS planned and conducted the research, and wrote the manuscript. JW, GW, DJ, DH, SH, MV and LR contributed to poster content and design. $\mathrm{SM}, \mathrm{GL}, \mathrm{MD}, \mathrm{ND}$ sand LR contributed to poster design and review and to manuscript preparation. All authors have read, reviewed and approved the final manuscript.

\section{Acknowledgements}

We kindly thank all poster reviewers from the AELG, BoP ELG, NZ Ministry of Health and ESR. Special thanks to Brian Park (WaterCare), Scott Muspratt (Vector Ltd), Bob Fletcher (Air NZ) and Peter Lechner (NZ CAA). Our sincere thanks to Tina Neal and Kristi Wallace from the Alaska Volcano Observatory for their review of posters and continuing support. Thanks also to Jim Cole for supporting the project. We acknowledge funding support from AELG, the DEVORA project (funded by the Earthquake Commission, Auckland Council and Ministry of Business, Innovation and Employment), and MBIE Research Contract C05X0907 (TW, CS, DJ).

\section{Author details}

${ }^{1}$ Volcanic Ash Testing Lab, Department of Geological Sciences, University of Canterbury, Private Bag 4800, Christchurch 8140, New Zealand. ${ }^{2}$ Joint Centre for Disaster Research, Massey University/GNS Science, Wellington, New Zealand. ${ }^{3}$ GNS Science, Lower Hutt, New Zealand. ${ }^{4}$ Auckland Engineering Lifelines Group Project Coordinator, Infrastructure Decisions Limited, Auckland, New Zealand.

Received: 19 February 2014 Accepted: 18 July 2014

Published: 5 August 2014

\section{References}

Alexander D (2007) Making research on geological hazards relevant to stakeholders' needs. Quaternary Int 171-172:186-192

Ballantyne M, Paton D, Johnston D, Kozuch M, Daly M (2000) Information on volcanic and earthquake hazards: the impact on awareness and preparation. Institute of Geological \& Nuclear Sciences Limited Science Report 2000/2 Lower Hutt, p 90

Berlo DK (1960) The process of communication. Holt, Rinehart \& Winston, New York

Blong RJ (1984) Volcanic Hazards: A Sourcebook on the Effects of Eruptions. Academic Press, Sydney
Buteler M, Stadler T, Lopez Garcia GP, Lassa MS, Trombotto Liaudat D, D'Adamo P, Fernandez-Arhex V (2011) Propiedades insecticidas de la ceniza del complejo volcanic Puyehue-Cordon Caulleny su possible impacto ambiental. Rev Soc Entomol Argent 70:149-156. Abstract in English

Covello VT, Allen F (1988) Seven Cardinal Rules of Risk Communication. U.S. Environmental Protection Agency. Policy Document OPA-87-020, Washington, D.C

Few R, Barclay J (2011) Societal Impacts of Natural Hazards, a review of international research funding. UK Collaborative on Development Sciences, London. Available from: http://www.ukcds.org.uk/resources/societal-impactsof-natural-hazards-a-review-of-international-research-funding

ICAO (2007) Manual on Volcanic Ash, Radioactive Material and Toxic Chemical Clouds. Doc 9691 AN/954, International Civil Aviation Organization, p 159p. Available from www.paris.icao.int/news/pdf/9691.pdf

ICSU (2003) Priority Area Assessment on Environment and its Relation to Sustainable Development. International Council for Science, Paris. Available from: http://www.icsu.org/publications/reports-and-reviews/priority-areaassessment-on-environment-and-its-relation-to-sustainable-development/ priority-area-assessment-on-environment-and-its-relation-to-sustainabledevelopment

ICSU (2008) A Science Plan for Integrated Research on Disaster Risk (IRDR) International Council for Science, Paris. Available from: http://www.icsu.org/ publications/reports-and-reviews/IRDR-science-plan/irdr-science-plan.pdf

ICSU (2010) Regional Environmental Change: Human Action and Adaptation. What does it take to meet the Belmont Challenge? Preliminary report of an ad hoc ICSU panel. International Council for Science, Paris. Available from: http://www.icsu.org/publications/reports-and-reviews/belmont-report/ regional-environmental-change-human-action-and-adaptation-1

Johnston DM, Bebbington M, Lai C-D, Houghton BF, Paton D (1999) Volcanic hazard perceptions: comparative shifts in knowledge and risk. Disast Prev Manag 8:118-126

Johnston DM, Houghton B, Neall VE, Ronan KR, Paton D (2000) Impacts of the 1945 and 1995-1996 Ruapehu eruptions, New Zealand: an example of increasing societal vulnerability. Geol Soc Am Bull 112(5):720-726

Leonard GS, Johnston DM, Paton D, Christianson A, Becker JS, Keys H (2008) Developing effective warning systems: ongoing research at Ruapehu volcano, New Zealand. J Volcanol Geotherm Res 172(3/4):199-215

Lindsay J, Marzocchi W, Jolly G, Constantinescu R, Selva J, Sandri L (2010) Towards real-time eruption forecasting in the Auckland Volcanic Field: application of BET_EF during the New Zealand National Disaster Exercise 'Ruaumoko'. Bull Volcanol 72(2):185-204

McBean GA (2012) Integrating disaster risk reduction towards sustainable development. Curr Opin Environ Sustain 4:122-127

Miletti D (1999) Disasters by Design. Joseph Henry Press, Washington, DC

NELC (2007) National Engineering Lifeline Committee Brochure. Available from http://www.civildefence.govt.nz/assets/Uploads/publications/nzlcbrochure.pdf; Accessed on 13 October 2013

OCDESC (2007) National Hazardscape Report. Officials' Committee for Domestic and External Security Coordination. Department of the Prime Minister and Cabinet, New Zealand, p 14p

Paton D, Johnston DM, Houghton BF (1998) Organisational response to a volcanic eruption. Disast Prev Manag 7:5-13

Paton D, Smith L, Johnston DM (2005) When good intentions turn bad: promoting natural hazard preparedness. Australian J Emerg Manag 20(1):25-30

Paton D, Smith L, Daly M, Johnston DM (2008) Risk perception and volcanic hazard mitigation: Individual and social perspectives. J Volcanol Geotherm Res 172:179-188

Ronan KR, Paton D, Johnston DM, Houghton BF (2000) Managing societal uncertainty in volcanic hazards: a multidisciplinary approach. Disast Prev Manag 9(5):339-348

Stewart C, Johnston DM, Leonard GS, Horwell CJ, Thordarsson T, Cronin SJ (2006) Contamination of water supplies by volcanic ashfall: a literature review and simple impact modelling. J Volcanol Geotherm Res 158:296-306

Stewart C, Pizzolon L, Wilson TM, Leonard GS, Dewar D, Johnston DM, Cronin SJ (2009) Can volcanic ash poison water supplies? Integr Environ Assess Manag 5(4):713-716

Sword-Daniels V, Wilson TM, Sargeant S, Rossetto T, Twigg J, Johnston DM, Loughlin SC, Cole PD (2014) Consequences of long-term volcanic activity for essential services in Montserrat: challenges, adaptations and resilience. In: Memoir of the Geological Society of London Special volume "The Eruption of Soufriere Hills Volcano". in press 
Tobin GA, Montz BE (1997) Natural Hazards. Guilford Press, New York

Twigg J (2007) Characteristics of a disaster-resilient community: a guidance note. DFID Disaster Risk Reduction Interagency Coordination Group. Accessed 30 January 2014; Available from: https://practicalaction.org/docs/ia1/communitycharacteristics-en-lowres.pdf

UNISDR (2011) HFA Progress in Asia-Pacific: Regional Synthesis Report 2009-2011. United Nations Office for Disaster Risk Reduction - Regional Office for Asia and Pacific (UNISDR AP), p 37 p

VISG (2012) Volcanic Impacts Study Group Charter. Auckland Engineering Lifelines Group. Available from http://www.aelg.org.nz/volcanic-impacts/ about-visg/; Accessed on 10 August 2013

Wachinger G, Renn O, Begg C, Kuhlicke C (2013) The Risk Perception Paradox-Implications for Governance and Communication of Natural Hazards. Risk Anal 33(6):1049-1065

Wardman JB, Wilson TM, Bodger PS, Cole JW, Stewart C (2012a) Potential impacts from tephra fall to electric power systems: A review and mitigation strategies. Bull Volcanol 74(10):2221-2241

Wardman JB, Wilson TM, Bodger PS, Cole JW, Johnston DM (2012b) Investigating the electrical conductivity of volcanic ash and its effect on $\mathrm{HV}$ power systems. Physics and Chemistry of the Earth, Parts A/B/C 45-46:128-145

Wilson G, Wilson TM, Cole JW, Oze C (2012a) Vulnerability of laptop computers to volcanic ash and gas. Nat Hazards 63(2):711-736

Wilson TM, Stewart C, Sword-Daniels V, Leonard GS, Johnston DM, Cole JW, Wardman J, Wilson G, Barnard ST (2012b) Volcanic ash impacts on critical infrastructure. Physics and Chemistry of the Earth, Parts A/B/C 45-46:5-23

Wilson T, Stewart C, Bickerton H, Baxter P, Outes V, Villarosa G, Rovere E (2012C) The health and environmental impacts of the June 2011 Puyehue-Cordón Caulle volcanic eruption: a preliminary report. GNS Science Report 2012/20, p 27

doi:10.1186/s13617-014-0010-x

Cite this article as: Wilson et al: Volcanic ashfall preparedness poster series: a collaborative process for reducing the vulnerability of critical infrastructure. Journal of Applied Volcanology 2014 3:10.

\section{Submit your manuscript to a SpringerOpen ${ }^{\circ}$ journal and benefit from:}

- Convenient online submission

- Rigorous peer review

- Immediate publication on acceptance

- Open access: articles freely available online

- High visibility within the field

- Retaining the copyright to your article

Submit your next manuscript at $\gg$ springeropen.com 